\title{
Niobium tetrachloride complexes with thio-, seleno- and telluro-ether coordination - synthesis and structures
}

\author{
Yao-Pang Chang, William Levason, ${ }^{*}$ Mark E. Light and Gillian Reid \\ Chemistry, University of Southampton, Highfield, Southampton SO17 1BJ, UK
}

\begin{abstract}
$\mathrm{NbCl}_{4}$ reacts with the dithioethers $\mathrm{MeS}\left(\mathrm{CH}_{2}\right)_{n} \mathrm{SMe}\left(\mathrm{n}=2\right.$ or 3), ${ }^{\mathrm{i}} \mathrm{PrS}\left(\mathrm{CH}_{2}\right)_{2} \mathrm{~S}$ Pr or $o-\mathrm{C}_{6} \mathrm{H}_{4}\left(\mathrm{CH}_{2} \mathrm{SEt}\right)_{2}$ in a 1: 1 molar ratio in $\mathrm{CH}_{2} \mathrm{Cl}_{2}$ or toluene over several days, to give red or orange, paramagnetic complexes, $\left[\mathrm{NbCl}_{4}\right.$ (dithioether)]. Their X-ray crystal structures confirm distorted octahedral geometries with chelating dithioether. $\mathrm{MeS}\left(\mathrm{CH}_{2}\right)_{2} \mathrm{SMe}$, alone, also forms an $\left[\mathrm{NbCl}_{4}\left\{\mathrm{MeS}\left(\mathrm{CH}_{2}\right)_{2} \mathrm{SMe}\right\}_{2}\right]$ complex based upon eightcoordinate $\mathrm{Nb}(\mathrm{IV})$ in a square antiprismatic geometry. Similar six-coordinate cis-[ $\mathrm{NbCl}_{4}($ diselenoether $\left.)\right]$ are formed by $\mathrm{MeSe}\left(\mathrm{CH}_{2}\right)_{n} \mathrm{SeMe}\left(\mathrm{n}=2\right.$ or 3) and ${ }^{\mathrm{n}} \mathrm{BuSe}\left(\mathrm{CH}_{2}\right)_{3} \mathrm{Se}^{\mathrm{n}} \mathrm{Bu}$. The monodentate ligands $\mathrm{Me}_{2} \mathrm{~S}, \mathrm{Me}_{2} \mathrm{Se}$ and ${ }^{n} \mathrm{Bu}_{2} \mathrm{Se}$ form $\left[\mathrm{NbCl}_{4}\left(\mathrm{R}_{2} \mathrm{E}\right)_{2}\right](\mathrm{E}=\mathrm{S}, \mathrm{Se})$ which are unstable in solution, losing $\mathrm{R}_{2} \mathrm{E}$ to form complexes with a 1:1 stoichiometry, which are shown to be diamagnetic dimers, $\left[\left(\mathrm{Me}_{2} \mathrm{E}\right) \mathrm{Cl}_{3} \mathrm{Nb}(\mu-\mathrm{Cl})_{2} \mathrm{NbCl}_{3}\left(\mathrm{Me}_{2} \mathrm{E}\right)\right]$, with single $\mathrm{Nb}-\mathrm{Nb} \sigma$-bonds. Tellurium ligands tend to decompose in these reactions, but reaction at room temperature of $\mathrm{Me}_{2} \mathrm{Te}$ and $\mathrm{NbCl}_{4}$ formed $\left[\mathrm{NbCl}_{4}\left(\mathrm{Me}_{2} \mathrm{Te}\right)_{2}\right]$, the X-ray structure of which revealed an eightcoordinate dimer, $\left[\mathrm{Nb}_{2} \mathrm{Cl}_{4}(\mu-\mathrm{Cl})_{4}\left(\mathrm{Me}_{2} \mathrm{Te}\right)_{4}\right]$. The new complexes have been characterised by microanalysis, IR, UV-visible spectroscopy and magnetic measurements. X-ray crystal structures are reported for $\left[\mathrm{NbCl}_{4}(\mathrm{~L}-\mathrm{L})\right]\left(\mathrm{L}-\mathrm{L}=\mathrm{MeS}\left(\mathrm{CH}_{2}\right)_{n} \mathrm{SMe}, \mathrm{n}=2\right.$ or $3,{ }^{\mathrm{i}} \mathrm{PrS}\left(\mathrm{CH}_{2}\right)_{2} \mathrm{~S}$ Pro, $\left.o-\mathrm{C}_{6} \mathrm{H}_{4}\left(\mathrm{CH}_{2} \mathrm{SEt}\right)_{2}, \mathrm{MeSe}\left(\mathrm{CH}_{2}\right)_{3} \mathrm{SeMe}\right)$, $\left[\mathrm{Nb}_{2} \mathrm{Cl}_{8}\left(\mathrm{Me}_{2} \mathrm{Te}\right)_{4}\right],\left[\mathrm{Nb}_{2} \mathrm{Cl}_{8}\left(\mathrm{Me}_{2} \mathrm{~S}\right)_{2}\right]$ and $\left[\mathrm{Nb}_{2} \mathrm{Cl}_{8}\left(\mathrm{Me}_{2} \mathrm{Se}\right)_{2}\right]$. The complexes are very sensitive to moisture and dioxygen, and some also readily undergo $\mathrm{C}-\mathrm{E}$ bond cleavage. Two ligand fragmentation products were identified - $\left[\mathrm{Nb}_{2} \mathrm{Cl}_{4}(\mu-\mathrm{S})_{2}\left\{\mathrm{MeS}\left(\mathrm{CH}_{2}\right)_{3} \mathrm{SMe}\right\}_{2}\right]$ and $\left[\mathrm{Nb}_{2} \mathrm{Cl}_{4}(\mu-\mathrm{Se})_{2}\left\{o-\mathrm{C}_{6} \mathrm{H}_{4}\left(\mathrm{CH}_{2}\right)_{2} \mathrm{Se}\right\}_{4}\right]$. X-ray crystal structures are also reported for the oxidation/hydrolysis products $\left[\mathrm{NbOCl}_{3}\left(\mathrm{Me}_{2} \mathrm{~S}\right)\right]$ and $\left[\mathrm{NbOCl}_{3}\left\{\mathrm{MeS}\left(\mathrm{CH}_{2}\right)_{2} \mathrm{SMe}\right\}\right]$.
\end{abstract}

\section{Introduction}

Although typically considered as soft, modest $\sigma$-donors, thioethers form complexes with most transition metals, including the earlier d-block elements in higher oxidation states. ${ }^{1-3}$ Less is known about the corresponding selenoether complexes, and very few examples early transition metal complexes with telluroethers are known. ${ }^{2}$ In addition to their inherent interest, such complexes may function as precursors to the corresponding semiconducting metal dichalcogenides, which are important in electronic, magnetic and energy storage applications. ${ }^{4,5}$ The properties of the metal dichalcogenides $\mathrm{ME}_{2}(\mathrm{M}=\mathrm{Nb}, \mathrm{Ta}, \mathrm{Mo}, \mathrm{W}, \mathrm{E}=\mathrm{S}$, $\mathrm{Se}, \mathrm{Te}$ ) may be tuned by choice of metal and chalcogen, and particular interest lies in the growth of thin films which maximise the anisotropy of the properties. Techniques available to produce such thin films

\footnotetext{
* Corresponding author. Email: wx1@soton.ac.uk
} 
include atomic layer deposition, physical vapour deposition, exfoliation of bulk samples and especially chemical vapour deposition (CVD). ${ }^{6}$ Examples of early transition metal sulfide and selenide films deposited by CVD techniques include $\mathrm{ME}_{2}(\mathrm{M}=\mathrm{Ti}, \mathrm{V}, \mathrm{Nb}, \mathrm{Ta}, \mathrm{Mo}, \mathrm{W})$, although single-source reagents that successfully deposit metal ditellurides are still unknown for the early transition metals. ${ }^{7-9}$ We have reported that low pressure CVD of thin films of $\mathrm{NbS}_{2}$ and $\mathrm{NbSe}_{2}$ can be achieved using the corresponding $\mathrm{Nb}(\mathrm{V})$ complexes, $\left[\mathrm{NbCl}_{5}\left({ }^{\mathrm{n}} \mathrm{Bu}_{2} \mathrm{E}\right)\right]$, the n-butyl substituent offering the low energy decomposition pathway of $\beta$ hydride elimination. ${ }^{10}$ Attempts to utilise the niobium(III) dimers, $\left[\mathrm{Nb}_{2} \mathrm{Cl}_{4}\left(\mathrm{R}_{2} \mathrm{~S}\right)_{2}(\mu-\mathrm{Cl})_{2}\left(\mu-\mathrm{R}_{2} \mathrm{~S}\right)\right]$ or $\left.\left[\mathrm{Nb}_{2} \mathrm{Cl}_{4}\left\{\mathrm{RE}\left(\mathrm{CH}_{2}\right)_{\mathrm{n}} \mathrm{ER}\right)\right\}_{2}(\mu-\mathrm{Cl})_{2}\right]\left(\mathrm{R}=\mathrm{Me},{ }^{\mathrm{n}} \mathrm{Bu} ; \mathrm{n}=2\right.$ or 3$)$, as low pressure CVD precursors failed, due to their low volatility, whilst their poor solubility in appropriate solvents ruled out aerosol assisted CVD. ${ }^{11}$

Niobium(V) thioether complexes include the six-coordinate $\left[\mathrm{NbX}_{5}\left(\mathrm{R}_{2} \mathrm{E}\right)\right](\mathrm{R}=\mathrm{Me}$ or Et; $\mathrm{X}=\mathrm{F}, \mathrm{Cl}$, $\mathrm{Br}],{ }^{10,12,13}\left[\left(\mathrm{NbX}^{\prime}{ }_{5}\right)_{2}\left\{\mu-\mathrm{RS}\left(\mathrm{CH}_{2}\right)_{n} \mathrm{SR}\right\}\right]\left(\mathrm{X}^{\prime}=\mathrm{Cl}\right.$ or $\left.\mathrm{Br}\right),\left[\left(\mathrm{NbX}^{\prime}\right)_{2}\left\{\mu-o-\mathrm{C}_{6} \mathrm{H}_{4}\left(\mathrm{CH}_{2} \mathrm{SR}\right)_{2}\right\}\right]$ and the eight-

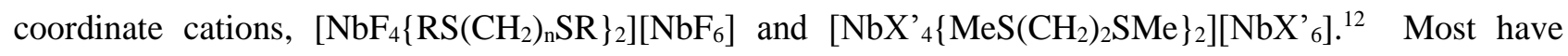
rather less stable selenium analogues, except that diselenoethers do not form eight-coordinate cations, the fluorides giving only rather unstable $\left[\left(\mathrm{NbF}_{5}\right)_{2}\left\{\mu-\mathrm{RSe}\left(\mathrm{CH}_{2}\right)_{n} \mathrm{SeR}\right\}\right] .{ }^{12}$ The niobium(III) complexes include the confacial bi-octahedral $\quad\left[\mathrm{Nb}_{2} \mathrm{Cl}_{4}\left(\mathrm{R}_{2} \mathrm{~S}\right)_{2}(\mu-\mathrm{Cl})_{2}\left(\mu-\mathrm{R}_{2} \mathrm{~S}\right)\right]$ and the edge-shared dimers, $\left[\mathrm{Nb}_{2} \mathrm{Cl}_{4}\left\{\mathrm{RE}\left(\mathrm{CH}_{2}\right)_{2} \mathrm{SER}\right\}_{2}(\mu-\mathrm{Cl})_{2}\right](\mathrm{E}=\mathrm{S}$ or $\mathrm{Se}),{ }^{11}$ all which contain $\mathrm{Nb}_{2}{ }^{6+}$ units with $\mathrm{Nb}=\mathrm{Nb}$ double bonds. Further complexity in the area results from the formation of sulfide or selenide bridged $\mathrm{Nb}_{2}{ }^{8+}$ species with single $\mathrm{Nb}-\mathrm{Nb}$ bonds, where the chalcogenide groups come from $\mathrm{C}-\mathrm{E}$ bond fission in the chalcogenoethers; some of these complexes were initially erroneously identified as chloride bridged $\mathrm{Nb}_{2}{ }^{6+}$ type. ${ }^{11,14}$ Reports of mononuclear niobium(IV) complexes with thioethers are very old and describe $\left[\mathrm{NbX}_{4} \mathrm{~L}_{\mathrm{n}}\right]$ ( $\mathrm{X}=\mathrm{Cl}$, Br or I; $\mathrm{L}$ $=\mathrm{Me}_{2} \mathrm{~S}$, tetrahydrothiophene; $\mathrm{n}=1$ or 2$)$ and $\left[\mathrm{NbX}_{4}\left\{\mathrm{MeS}\left(\mathrm{CH}_{2}\right)_{2} \mathrm{SMe}\right\}_{2}\right]$, although with limited spectroscopic and no crystallographic data. ${ }^{15-17}$ There are no reports of selenoether or telluroether analogues.

Here we report a systematic study of the synthesis, properties and structures of $\mathrm{Nb}(\mathrm{IV})$ thio-, seleno- and telluro-ethers. We have recently reported complexes of $\mathrm{NbCl}_{4}$ and $\mathrm{NbBr}_{4}$ with various diphosphines ${ }^{18}$ which provide useful comparisons with the present complexes.

\section{Experimental}

$\mathrm{NbCl}_{4}$ was prepared as described previously. ${ }^{18}$ Chalcogenoethers, $\mathrm{MeE}\left(\mathrm{CH}_{2}\right)_{\mathrm{n}} \mathrm{EMe}(\mathrm{E}=\mathrm{S}, \mathrm{Se} ; \mathrm{n}=2,3)$, ${ }^{i} \mathrm{PrS}\left(\mathrm{CH}_{2}\right)_{n} \mathrm{~S}^{\mathrm{i}} \mathrm{Pr}, \quad{ }^{\mathrm{n}} \mathrm{BuSe}\left(\mathrm{CH}_{2}\right)_{3} \mathrm{Se}^{\mathrm{n}} \mathrm{Bu}, \quad{ }^{\mathrm{t}} \mathrm{BuTe}\left(\mathrm{CH}_{2}\right)_{3} \mathrm{Te}{ }^{\mathrm{t} B u}, \quad o-\mathrm{C}_{6} \mathrm{H}_{4}(\mathrm{TeMe})_{2}, \quad o-\mathrm{C}_{6} \mathrm{H}_{4}\left(\mathrm{CH}_{2} \mathrm{SMe}\right)_{2}, \quad o-$ $\mathrm{C}_{6} \mathrm{H}_{4}\left(\mathrm{CH}_{2} \mathrm{SeMe}\right)_{2}, \mathrm{Me}_{2} \mathrm{Te}$ and ${ }^{\mathrm{n}} \mathrm{Bu}_{2} \mathrm{Se}$ were prepared via literature methods or minor modifications thereof. ${ }^{19,20} \mathrm{Me}_{2} \mathrm{~S}$ and $\mathrm{Me}_{2} \mathrm{Se}$ were obtained from Sigma Aldrich. Infrared spectra were recorded using a Perkin-Elmer Spectrum 100 spectrometer in the range 4000-200 $\mathrm{cm}^{-1}$, with the samples prepared as Nujol mulls or as thin films between CsI plates. UV/visible spectra were recorded as powdered solids diluted with $\mathrm{BaSO}_{4}$, using the diffuse reflectance attachment of a Perkin Elmer 750S spectrometer. Magnetic measurements were made on a Johnson Matthey magnetic balance. ${ }^{1} \mathrm{H}$ and ${ }^{13} \mathrm{C}\left\{{ }^{1} \mathrm{H}\right\}$ NMR spectra were recorded from $\mathrm{CD}_{2} \mathrm{Cl}_{2}$ solutions using a Bruker AV II 400 spectrometer. Microanalyses were performed by London Metropolitan University. Preparations used standard Schlenk and glove box techniques under a $\mathrm{N}_{2}$ 
atmosphere with rigorous exclusion of moisture. Solvents were dried by distillation from $\mathrm{CaH}_{2}\left(\mathrm{CH}_{2} \mathrm{Cl}_{2}\right)$ or $\mathrm{Na} /$ benzophenone ketyl (toluene, $\mathrm{n}$-hexane).

\section{X-ray experimental:}

Data collections used a Rigaku AFC12 goniometer equipped with an enhanced sensitivity (HG) Saturn724+ detector mounted at the window of an FR-E + SuperBright molybdenum $(\lambda=0.71073)$ rotating anode generator with VHF Varimax optics (70 micron focus) with the crystal held at $100 \mathrm{~K}\left(\mathrm{~N}_{2}\right.$ cryostream). Structure solution and refinement were performed using SHELX(S/L)97, SHELX-2014/7 and were

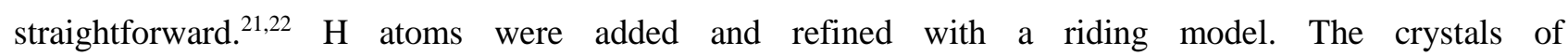
$\left[\mathrm{NbCl}_{4}\left\{\mathrm{MeS}\left(\mathrm{CH}_{2}\right)_{3} \mathrm{SMe}\right\}\right]$ were twinned and this was modelled with a 45:55 ratio.

\section{$\left[\mathrm{NbCl}_{4}\left\{\mathrm{MeS}\left(\mathrm{CH}_{2}\right)_{2} \mathrm{SMe}_{2}\right]\right.$}

$\mathrm{NbCl}_{4}(82 \mathrm{mg}, 0.35 \mathrm{mmol})$ was suspended in toluene $(5 \mathrm{~mL})$ at room temperature. A solution of $\mathrm{MeS}\left(\mathrm{CH}_{2}\right)_{2} \mathrm{SMe}(640 \mathrm{mg}, 5.24 \mathrm{mmol})$ in toluene $(5 \mathrm{ml})$ was added and the solution stirred for 3 days. After filtering off any remaining solid, the solution was taken to dryness in vacuo, leaving a sticky brown solid. The brown solid was dissolved in $\mathrm{CH}_{2} \mathrm{Cl}_{2}(30 \mathrm{~mL})$, filtered, and the red brown filtrate taken to dryness in vacuo to give a brown powder. Yield: $19 \mathrm{mg}, 11 \%$. Required for $\mathrm{C}_{8} \mathrm{H}_{20} \mathrm{Cl}_{4} \mathrm{NbS}_{4}$ (479.22): C, 20.05; H, 4.21. Found: C, 19.92; H, 4.12\%. IR (Nujol, $\left.\mathrm{cm}^{-1}\right): 305 \mathrm{~s}, 282 \mathrm{~s}(\mathrm{Nb}-\mathrm{Cl})$. UV/vis (diffuse reflectance)/ $\mathrm{cm}^{-1}: 42370$, 32 900, 24 940, 18 830, 14 290, 11 050. Red crystals were grown by allowing a $\mathrm{CH}_{2} \mathrm{Cl}_{2}$ solution to evaporate under a $\mathrm{N}_{2}$ atmosphere.

\section{$\left[\mathrm{NbCl}_{4}\left\{\mathrm{MeS}\left(\mathrm{CH}_{2}\right)_{2} \mathrm{SMe}\right\}\right]$}

$\mathrm{NbCl}_{4}(71 \mathrm{mg}, 0.3 \mathrm{mmol})$ was suspended in $\mathrm{CH}_{2} \mathrm{Cl}_{2}(10 \mathrm{~mL})$ at room temperature. A solution of $\mathrm{MeS}\left(\mathrm{CH}_{2}\right)_{2} \mathrm{SMe}(36 \mathrm{mg}, 0.3 \mathrm{mmol})$ in $\mathrm{CH}_{2} \mathrm{Cl}_{2}(2 \mathrm{~mL})$ was added and the solution stirred for 3 days. After filtering, the orange solution was evaporated in vacuo. $\mathrm{n}$-Hexane $(10 \mathrm{~mL})$ was added to wash the solid and the washings removed via a syringe. The dark brown solid was dried in vacuo. Yield: $74 \mathrm{mg}, 69 \%$. Microanalyses were typically high in C, due to some of the 2:1 complex present - see text. IR (Nujol, $\mathrm{cm}^{-1}$ ): $350,335,325 \mathrm{sh}, 312 \mathrm{sh}(\mathrm{Nb}-\mathrm{Cl})$. Red crystals were grown by allowing a $\mathrm{CH}_{2} \mathrm{Cl}_{2}$ solution to evaporate under a $\mathrm{N}_{2}$ atmosphere.

\section{$\left[\mathrm{NbCl}_{4}\left\{{ }^{\mathrm{i}} \operatorname{PrS}\left(\mathrm{CH}_{2}\right)_{2} \mathrm{~S}^{\mathrm{i}} \mathrm{Pr}\right\}\right]$}

$\mathrm{NbCl}_{4}(70 \mathrm{mg}, 0.3 \mathrm{mmol})$ was suspended in $\mathrm{CH}_{2} \mathrm{Cl}_{2}(15 \mathrm{~mL})$ at room temperature. A solution of ${ }^{i} \operatorname{PrS}\left(\mathrm{CH}_{2}\right)_{2} \mathrm{~S}$ Pr $(53 \mathrm{mg}, 0.3 \mathrm{mmol})$ in $\mathrm{CH}_{2} \mathrm{Cl}_{2}(2 \mathrm{~mL})$ was added and the solution stirred for 3 days. The colour of the solution changed to red brown. The solution was filtered and the solvent removed in vacuo, leaving a sticky dark brown solid. $\mathrm{n}$-Hexane $(4 \mathrm{~mL})$ was added, the suspension stirred and the solid filtered off. The solid was dried in vacuo and leaving a red brown powder. Yield: $65 \mathrm{mg}, 52.5 \%$. Required for $\mathrm{C}_{8} \mathrm{H}_{18} \mathrm{Cl}_{4} \mathrm{NbS}_{2}$ (413.08): C, 23.26; H, 4.39. Found: C, 23.42; H, 4.46\%. IR (Nujol, $\mathrm{cm}^{-1}$ ): 368sh, 353s, 339sh, 319sh (Nb-Cl). UV/vis (diffuse reflectance)/cm $\mathrm{cm}^{-1}: 34$ 500, 29 675, 24 270, 19 720, 14 700, 10730. 
Alternative method: $\mathrm{NbCl}_{4}(70 \mathrm{mg}, 0.3 \mathrm{mmol})$ was suspended in toluene $(15 \mathrm{~mL})$ and ${ }^{\mathrm{i}} \operatorname{PrS}\left(\mathrm{CH}_{2}\right)_{2} \mathrm{~S} \operatorname{Pr}(108$ $\mathrm{mg}, 0.6 \mathrm{mmol}$ ) added at room temperature. After stirring for 5 days, the brown solution was filtered and the filtrate taken to dryness vacuo, affording a sticky red-brown solid. This was washed with $\mathrm{n}$-hexane $(5 \mathrm{~mL})$ and the solid filtered off and dried in vacuo to give a red powder. Yield: $58 \mathrm{mg}, 47 \%$. Required for $\mathrm{C}_{8} \mathrm{H}_{18} \mathrm{Cl}_{4} \mathrm{NbS}_{2}$ (413.08): C, 23.26; H, 4.39. Found: C, 23.87; H, 4.39\%. The product was spectroscopically identical to that from the other method. Red crystals were grown by allowing a $\mathrm{CH}_{2} \mathrm{Cl}_{2}$ solution to evaporate under a $\mathrm{N}_{2}$ atmosphere.

\section{$\left[\mathrm{NbCl}_{4}\left\{\mathrm{MeS}\left(\mathrm{CH}_{2}\right)_{3} \mathrm{SMe}\right\}\right]$}

$\mathrm{NbCl}_{4}$ (70 mg, $0.3 \mathrm{mmol}$ ) was suspended in $\mathrm{CH}_{2} \mathrm{Cl}_{2}(10 \mathrm{~mL})$ and a $\mathrm{CH}_{2} \mathrm{Cl}_{2}$ solution $(5 \mathrm{~mL}) \mathrm{MeS}\left(\mathrm{CH}_{2}\right)_{3} \mathrm{SMe}$ (40 mg, $0.3 \mathrm{mmol}$ ) was added and with stirred for 3 days. After filtered off any remaining solid, the redyellow filtrate was taken to dryness in vacuo, leaving a sticky brown solid. This was washed with n-hexane $(5 \mathrm{~mL})$, filtered off and dried in vacuo, affording a brown powder. Yield: $30 \mathrm{mg}, 27 \%$. Required for $\mathrm{C}_{5} \mathrm{H}_{12} \mathrm{Cl}_{4} \mathrm{NbS}_{2}$ (371.0): C, 16.19; H, 3.26. Found: C, 16.31; H, 3.3\%. IR (Nujol, $\mathrm{cm}^{-1}$ ): 356, 350, 340, 325 (Nb-Cl). UV/vis (diffuse reflectance)/cm ${ }^{-1} 43$ 670sh, 32 260, 21 000, 19 200, 11900.

A mixture of yellow (minor) and red (major) crystals were grown from a 1:1 mixture of $\mathrm{NbCl}_{4}$ and $\mathrm{MeS}\left(\mathrm{CH}_{2}\right)_{3} \mathrm{SMe}$ in $\mathrm{CH}_{2} \mathrm{Cl}_{2}$ over $\sim 6$ weeks. The red crystals were found to be $\left[\mathrm{NbCl}_{4}\left\{\mathrm{MeS}\left(\mathrm{CH}_{2}\right)_{3} \mathrm{SMe}\right)\right]$, whilst the yellow crystals were $\left[\mathrm{Nb}_{2} \mathrm{Cl}_{4}(\mu-\mathrm{S})_{2}\left\{\mathrm{MeS}\left(\mathrm{CH}_{2}\right)_{3} \mathrm{SMe}\right\}_{2}\right]$ (see below).

\section{$\left[\mathrm{NbCl}_{4}\left\{o-\mathrm{C}_{6} \mathrm{H}_{4}\left(\mathrm{CH}_{2} \mathrm{SEt}\right)_{2}\right\}\right]$}

$\mathrm{NbCl}_{4}(70 \mathrm{mg}, 0.3 \mathrm{mmol})$ was suspended in $\mathrm{CH}_{2} \mathrm{Cl}_{2}(15 \mathrm{~mL})$ and a $\mathrm{CH}_{2} \mathrm{Cl}_{2}(2 \mathrm{~mL})$ of $o-\mathrm{C}_{6} \mathrm{H}_{4}\left(\mathrm{CH}_{2} \mathrm{SEt}\right)_{2}(68$ $\mathrm{mg}, 0.3 \mathrm{mmol}$ ) was added with stirring. After 2 days the yellow-orange solution, was filtered and the filtrate taken to dryness in vacuo. The product was washed with $\mathrm{n}$-hexane $(5 \mathrm{~mL})$ and dried in vacuo. Orange solid. Yield: $21 \mathrm{mg}, 15 \%$. Required for $\mathrm{C}_{12} \mathrm{H}_{18} \mathrm{Cl}_{4} \mathrm{NbS}_{2}$ (461.12): C, 31.26; H, 3.93. Found: C, 31.51; H, 4.06\%. IR (Nujol, $\mathrm{cm}^{-1}$ ): 365s, 341s. UV/vis (diffuse reflectance)/cm ${ }^{-1}:$ 43 100, 33 000, 27 020, $18730,13900$. Yellow crystals were grown by allowing a $\mathrm{CH}_{2} \mathrm{Cl}_{2}$ solution to evaporate under a $\mathrm{N}_{2}$ atmosphere.

\section{$\left[\mathrm{NbCl}_{4}\left\{\mathrm{MeSe}\left(\mathrm{CH}_{2}\right)_{2} \mathrm{SeMe}\right\}\right]$}

$\mathrm{NbCl}_{4}$ (70 mg, $0.3 \mathrm{mmol}$ ) was suspended in $\mathrm{CH}_{2} \mathrm{Cl}_{2}(15 \mathrm{~mL})$ and a solution of $\mathrm{MeSe}\left(\mathrm{CH}_{2}\right)_{2} \mathrm{SeMe}(66 \mathrm{mg}, 0.3$ $\mathrm{mmol}$ ) in $\mathrm{CH}_{2} \mathrm{Cl}_{2}(2 \mathrm{~mL})$ was added and stirred for 3 days. The orange solution was filtered, and the orange solid redissolved in $\mathrm{CH}_{2} \mathrm{Cl}_{2}(20 \mathrm{~mL})$. This solution was filtered and taken to dryness in vacuo. The product was stirred with $\mathrm{n}$-hexane $(5 \mathrm{~mL})$, collected by filtration and dried in vacuo, leaving an orange powder. Yield: $16 \mathrm{mg}, 12 \%$. Required for $\mathrm{C}_{5} \mathrm{H}_{12} \mathrm{Cl}_{4} \mathrm{NbSe}_{2}$ (450.76): C, 10.66; H, 2.24. Found: C, 10.77; H, 2.2\%. IR (Nujol, $\mathrm{cm}^{-1}$ ): 382sh, 372, $337(\mathrm{Nb}-\mathrm{Cl})$. UV/vis (diffuse reflectance)/cm ${ }^{-1}: 45$ 300, 34 250, 23 000, 13950 , 11250.

$\left[\mathrm{NbCl}_{4}\left\{\operatorname{MeSe}\left(\mathrm{CH}_{2}\right)_{3} \mathrm{SeMe}\right\}\right]$ 
$\mathrm{NbCl}_{4}$ (70 mg, $\left.0.3 \mathrm{mmol}\right)$ was suspended in $\mathrm{CH}_{2} \mathrm{Cl}_{2}(10 \mathrm{~mL})$ and $\mathrm{MeSe}\left(\mathrm{CH}_{2}\right)_{3} \mathrm{SeMe}(67 \mathrm{mg}, 0.3 \mathrm{mmol})$ in $\mathrm{CH}_{2} \mathrm{Cl}_{2}(5 \mathrm{~mL})$ was added and stirred for 2 days giving a green-brown solution. The solution was filtered and the brown filtrate was evaporated to dryness in vacuo. The dark brown solid was washed by n-hexane ( 5 $\mathrm{mL}$ ), and dried in vacuo. Yield: $29 \mathrm{mg}, 21 \%$. Required for $\mathrm{C}_{5} \mathrm{H}_{12} \mathrm{Cl}_{4} \mathrm{NbSe}_{2}$ (464.79): C, 12.92; H, 2.6. Found: C, 13.09; H, 2.69. IR (Nujol, $\left.\mathrm{cm}^{-1}\right): 359,345,323(\mathrm{Nb}-\mathrm{Cl})$. UV/vis (diffuse reflectance)/ $\mathrm{cm}^{-1}: 44$ 850, 36 600, 20 700, 19 350, 12 000, 10 950. Red crystals were grown by allowing a $\mathrm{CH}_{2} \mathrm{Cl}_{2}$ solution to evaporate under a $\mathrm{N}_{2}$ atmosphere.

\section{$\left[\mathrm{NbCl}_{4}\left[{ }^{\mathrm{n}} \mathrm{BuSe}\left(\mathrm{CH}_{2}\right)_{3} \mathrm{Se}^{\mathrm{n}} \mathrm{Bu}\right\}\right]$}

$\mathrm{NbCl}_{4}$ (70 mg, $0.3 \mathrm{mmol}$ ) was suspended in $\mathrm{CH}_{2} \mathrm{Cl}_{2}(10 \mathrm{~mL})$. A solution of ${ }^{\mathrm{n}} \mathrm{BuSe}\left(\mathrm{CH}_{2}\right)_{3} \mathrm{Se}{ }^{\mathrm{n}} \mathrm{Bu}(93 \mathrm{mg}, 0.3$ $\mathrm{mmol})$ in $\mathrm{CH}_{2} \mathrm{Cl}_{2}(5 \mathrm{~mL})$ was added and stirred for 3 days giving a yellow solution. This was filtered and the yellow filtrate evaporated in vacuo and leaving a red orange oil. $\mathrm{N}$-hexane $(4 \mathrm{~mL})$ was added and the mixture stirred. The orange sticky solid was filtered off and dried in vacuo. Yield: $29 \mathrm{mg}, 18 \%$. Required for $\mathrm{C}_{11} \mathrm{H}_{24} \mathrm{Cl}_{4} \mathrm{NbSe}_{2}$ (548.95): C, 24.07; H, 4.41. Found: C, 23.98; H, 4.69\%. IR (Nujol, cm ${ }^{-1}$ ): 376sh, 344 $(\mathrm{Nb}-\mathrm{Cl})$. UV/vis (diffuse reflectance)/cm $\mathrm{cm}^{-1}: 41$ 000, 34 600, 24 400, 20 400, 11600.

\section{$\left[\mathrm{NbCl}_{4}\left(\mathrm{Me}_{2} \mathrm{~S}\right)_{2}\right]$}

$\mathrm{NbCl}_{4}(70 \mathrm{mg}, 0.3 \mathrm{mmol})$ was suspended in $\mathrm{CH}_{2} \mathrm{Cl}_{2}(10 \mathrm{~mL})$ and $\mathrm{Me}_{2} \mathrm{~S}(2 \mathrm{~mL})$ was added with stirring for 1 h. The dark purple solution formed was filtered and the filtrate taken to dryness in vacuo in an ice bath. A dark purple sticky solid was left. Yield: $76 \mathrm{mg}$ 70\%. The complexes loses $\mathrm{Me}_{2} \mathrm{~S}$ on warming or in vacuo and a satisfactory microanalysis could not be obtained. IR (Nujol, $\mathrm{cm}^{-1}$ ): 380, 362, 343, $321(\mathrm{Nb}-\mathrm{Cl}) . \mathrm{A} \mathrm{CH}_{2} \mathrm{Cl}_{2}$ solution of the complex was allowed to evaporate under an nitrogen atmosphere, yielding yellow crystals identified as $\left[\mathrm{Nb}_{2} \mathrm{Cl}_{8}\left(\mathrm{Me}_{2} \mathrm{~S}\right)_{2}\right]$ from an X-ray structure determination.

\section{$\left[\mathrm{Nb}_{2} \mathrm{Cl}_{8}\left(\mathrm{Me}_{2} \mathrm{~S}\right)_{2}\right]$}

$\mathrm{NbCl}_{4}(105 \mathrm{mg}, 0.4 \mathrm{mmol})$ was stirred with a mixture of $\mathrm{Me}_{2} \mathrm{~S}(1 \mathrm{~mL})$ and $\mathrm{CH}_{2} \mathrm{Cl}_{2}(10 \mathrm{~mL})$. The solution was stirred for $1 \mathrm{~h}$ giving a dark purple solution. The solution was then filtered, the brown solid (27 $\mathrm{mg})$ obtained was identified as unreacted $\mathrm{NbCl}_{4}$ identified by its IR spectrum. The dark purple filtrate was diluted by $\mathrm{n}$-hexane $(50 \mathrm{~mL})$ and stirred overnight under a nitrogen flow, resulting in a brown precipitate. The top purple solution was removed by a syringe and the brown powder washed with $\mathrm{n}$-hexane $(10 \mathrm{~mL})$ and dried in vacuo. Yield: $27 \mathrm{mg}, 23 \%$. Required for $\mathrm{C}_{2} \mathrm{H}_{6} \mathrm{Cl}_{4} \mathrm{NbS}_{2}$ (296.85): C, 8.09; H, 2.04. Found: C, 8.26; H, 1.88. IR (Nujol, $\left.\mathrm{cm}^{-1}\right): 375 \mathrm{sh}, 351,336 \mathrm{sh}(\mathrm{Nb}-\mathrm{Cl})$. UV/vis (diffuse reflectance)/cm ${ }^{-1}: 34$ 480, 28 900, 21460 (sh), 19 680,9900 .

\section{$\left[\mathrm{NbCl}_{4}\left(\mathrm{Me}_{2} \mathrm{Se}\right)_{2}\right]$}

$\mathrm{NbCl}_{4}$ (70 mg, $0.3 \mathrm{mmol}$ ) was suspended in $\mathrm{CH}_{2} \mathrm{Cl}_{2}(15 \mathrm{~mL})$ and a solution of $\mathrm{Me}_{2} \mathrm{Se}$ (100 mg, $\left.0.9 \mathrm{mmol}\right)$ in $\mathrm{CH}_{2} \mathrm{Cl}_{2}(3 \mathrm{~mL})$ was added and the reaction mixture was stirred overnight. The brownish-green solution was filtered and the filtrate taken to dryness in vacuo with cooling to $0{ }^{\circ} \mathrm{C}$, producing a brown solid. Yield: 73 
mg, 54\%. Required for $\mathrm{C}_{4} \mathrm{H}_{12} \mathrm{Cl}_{4} \mathrm{NbSe}_{2}$ (452.78): C, 10.61; H, 2.67. Found: C, 10.78; H, 2.71\%. IR (Nujol,

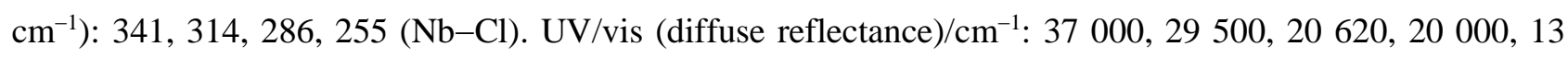
700sh, 10 800. Slow evaporation of a solution of the complex under nitrogen produced yellow crystals identified as $\left[\mathrm{Nb}_{2} \mathrm{Cl}_{8}\left(\mathrm{Me}_{2} \mathrm{Se}\right)_{2}\right]$.

\section{$\left[\mathrm{NbCl}_{4}\left({ }^{\mathrm{n}} \mathrm{Bu}_{2} \mathrm{Se}\right)_{2}\right]$}

Was made similarly from $\mathrm{NbCl}_{4}(70 \mathrm{mg}, 0.3 \mathrm{mmol})$ and ${ }^{\mathrm{n}} \mathrm{Bu}_{2} \mathrm{Se}(116 \mathrm{mg}, 0.6 \mathrm{mmol})$, and isolated as a sticky dark solid, after washing with n-hexane. Yield: $36 \mathrm{mg}, 19 \%$. Required for $\mathrm{C}_{16} \mathrm{H}_{36} \mathrm{Cl}_{4} \mathrm{NbSe}_{2}$ (621.09): C, 30.94; H, 5.84. Found: C, 31.08; H, 6.05\%. IR (Nujol, $\mathrm{cm}^{-1}$ ): 378, 343, 320sh (Nb-Cl). UV/vis (diffuse reflectance) $/ \mathrm{cm}^{-1}: 40$ 400, 35 000sh, 24 000, 14 200, $11380 \mathrm{sh}$.

\section{$\left[\mathrm{Nb}_{2} \mathrm{Cl}_{8}\left(\mathrm{Me}_{2} \mathrm{Te}\right)_{4}\right]$}

$\mathrm{NbCl}_{4}(70 \mathrm{mg}, 0.3 \mathrm{mmol})$ was placed in a Schlenk tube and a solution of $\mathrm{Me}_{2} \mathrm{Te}(142 \mathrm{mg}, 0.9 \mathrm{mmol})$ in $\mathrm{CH}_{2} \mathrm{Cl}_{2}(10 \mathrm{~mL})$ was added with stirring. The solution was stirred for 3 days at room temperature and formed a dark brown solution and some dark solid. The solution was filtered, giving a dark orange solid (47 mg) which was dried in vacuo. Yield: $47 \mathrm{mg}, 28 \%$. Required for $\mathrm{C}_{8} \mathrm{H}_{24} \mathrm{Cl}_{8} \mathrm{Nb}_{2} \mathrm{Te}_{4}$ (1100.1): C, 8.73; H, 2.20. Found: C, 8.80; H, 2.09\%. IR (Nujol, $\mathrm{cm}^{-1}$ ): 358w, 326br, 276, 250w (Nb-Cl). UV/vis (diffuse reflectance)/ $\mathrm{cm}^{-1} 32$ 260, 28 500, 19 800(sh), 17240 (sh), 9 300(br,w). Red crystals were grown by allowing a $\mathrm{CH}_{2} \mathrm{Cl}_{2}$ solution to evaporate under a $\mathrm{N}_{2}$ atmosphere.

\section{$\left[\mathrm{NbCl}_{4}\left\{{ }^{\mathrm{t}} \mathrm{BuTe}\left(\mathrm{CH}_{2}\right)_{3} \mathrm{Te}^{\mathrm{t}} \mathrm{Bu}\right\}_{2}\right]$}

$\mathrm{NbCl}_{4}$ (70 mg, $0.3 \mathrm{mmol}$ ) was suspended in $\mathrm{CH}_{2} \mathrm{Cl}_{2}(10 \mathrm{~mL})$. The Schlenk tube was covered with foil to exclude light and cooled in an ice bath. A solution of ${ }^{\mathrm{t}} \mathrm{BuTe}\left(\mathrm{CH}_{2}\right)_{3} \mathrm{Te} \mathrm{Bu}^{\mathrm{B}}(130 \mathrm{mg}, 0.3 \mathrm{mmol})$ in $\mathrm{CH}_{2} \mathrm{Cl}_{2}(2$ $\mathrm{mL}$ ) was added and the deep brown solution was stirred overnight and then filtered, the solid washed with $\mathrm{n}$ hexane $(10 \mathrm{~mL})$ and dried in vacuo, leaving a dark powder. Yield: $73 \mathrm{mg}, 37 \%$. Required for $\mathrm{C}_{22} \mathrm{H}_{48} \mathrm{Cl}_{4} \mathrm{NbTe}_{4}$ (1057.7): C, 24.98; H, 4.57. Found: C, 24.51; H, 4.81\%. IR (Nujol, $\mathrm{cm}^{-1}$ ): 355, 336, 320

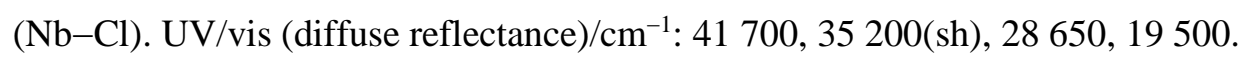

\section{$\left[\mathrm{Nb}_{2} \mathrm{Cl}_{4}\left(\mu-\mathrm{Se}_{\mathrm{x}}\right)(\boldsymbol{\mu}-\mathrm{Se})\left\{\boldsymbol{o}-\mathrm{C}_{6} \mathrm{H}_{4}\left(\mathrm{CH}_{2}\right)_{2} \mathrm{Se}\right\}_{4}\right](\mathrm{x}$ : see text)}

$\mathrm{NbCl}_{4}$ (70 mg, $0.3 \mathrm{mmol}$ ) was suspended in $\mathrm{CH}_{2} \mathrm{Cl}_{2}(15 \mathrm{~mL})$. A solution $o-\mathrm{C}_{6} \mathrm{H}_{4}\left(\mathrm{CH}_{2} \mathrm{SeMe}\right)_{2}(92.0 \mathrm{mg}, 0.3$ mmol $)$ in $\mathrm{CH}_{2} \mathrm{Cl}_{2}(2 \mathrm{~mL})$ was added and the mixture stirred for 2 days giving a brown solution. After removal of suspended solids by filtration, the brown solution was taken to dryness in vacuo. n-Hexane ( 5 $\mathrm{mL}$ ) was added and the solid produced filtered off and dried in vacuo. Dark brown powder. Yield: $70 \mathrm{mg}$, 34\%. Found: C, 27.0; H, 3.04\%. IR (Nujol, $\left.\mathrm{cm}^{-1}\right)$ : 365sh, 343sh, $330(\mathrm{Nb}-\mathrm{Cl}) .{ }^{1} \mathrm{H} \mathrm{NMR}\left(\mathrm{CDCl}_{3}, 295 \mathrm{~K}\right): \delta$ $=4.35\left(\mathrm{~s},[4 \mathrm{H}], \mathrm{CH}_{2}\right), 7.14-7.26(\mathrm{~m},[4 \mathrm{H}], \mathrm{Ar}) .{ }^{1} \mathrm{H} \mathrm{NMR}\left(\mathrm{CD}_{2} \mathrm{Cl}_{2}, 295 \mathrm{~K}\right): \delta=4.22\left(\mathrm{~s},[4 \mathrm{H}], \mathrm{CH}_{2}\right)$, 7.05-7.18 (m, [4H], Ar). ${ }^{13} \mathrm{C}\left\{{ }^{1} \mathrm{H}\right\} \mathrm{NMR}\left(\mathrm{CD}_{2} \mathrm{Cl}_{2}, 295 \mathrm{~K}\right): \delta=30.15\left(\mathrm{CH}_{2}\right), 126.38$ (Ar), 126.91(Ar). Yellowbrown crystals were grown by allowing a $\mathrm{CH}_{2} \mathrm{Cl}_{2}$ solution to evaporate under a $\mathrm{N}_{2}$ atmosphere.

\section{Results and Discussion}


As we noted in our recent study of $\mathrm{Nb}(\mathrm{IV})$-diphosphine complexes ${ }^{18}$ and as observed by other workers studying niobium phosphine ${ }^{23}$ or thioether complexes, ${ }^{14-17}$ small changes in the reaction conditions can result in different complexes or mixtures being formed, whilst reduction to $\mathrm{Nb}$ (III) species $^{11}$ or adventitious hydrolysis/oxidation to $\mathrm{Nb}(\mathrm{V})^{18}$ also occurs with ease. The preparations described below are those yielding single products often in poor to modest yield (Scheme 1), selected from a significantly larger number of reactions explored. The poor yields of some reactions reflect the fact that even after several days, significant amounts of unreacted $\mathrm{NbCl}_{4}$ remain (identified by the IR spectrum). Although $\left[\mathrm{NbCl}_{4}\left(\mathrm{MeCN}_{2}\right]\right.$ provided a soluble synthon for the diphosphine complexes, ${ }^{18}$ the thioethers do not cleanly replace the MeCN, hence $\mathrm{NbCl}_{4}$ was used, and the sometimes low yields accepted.

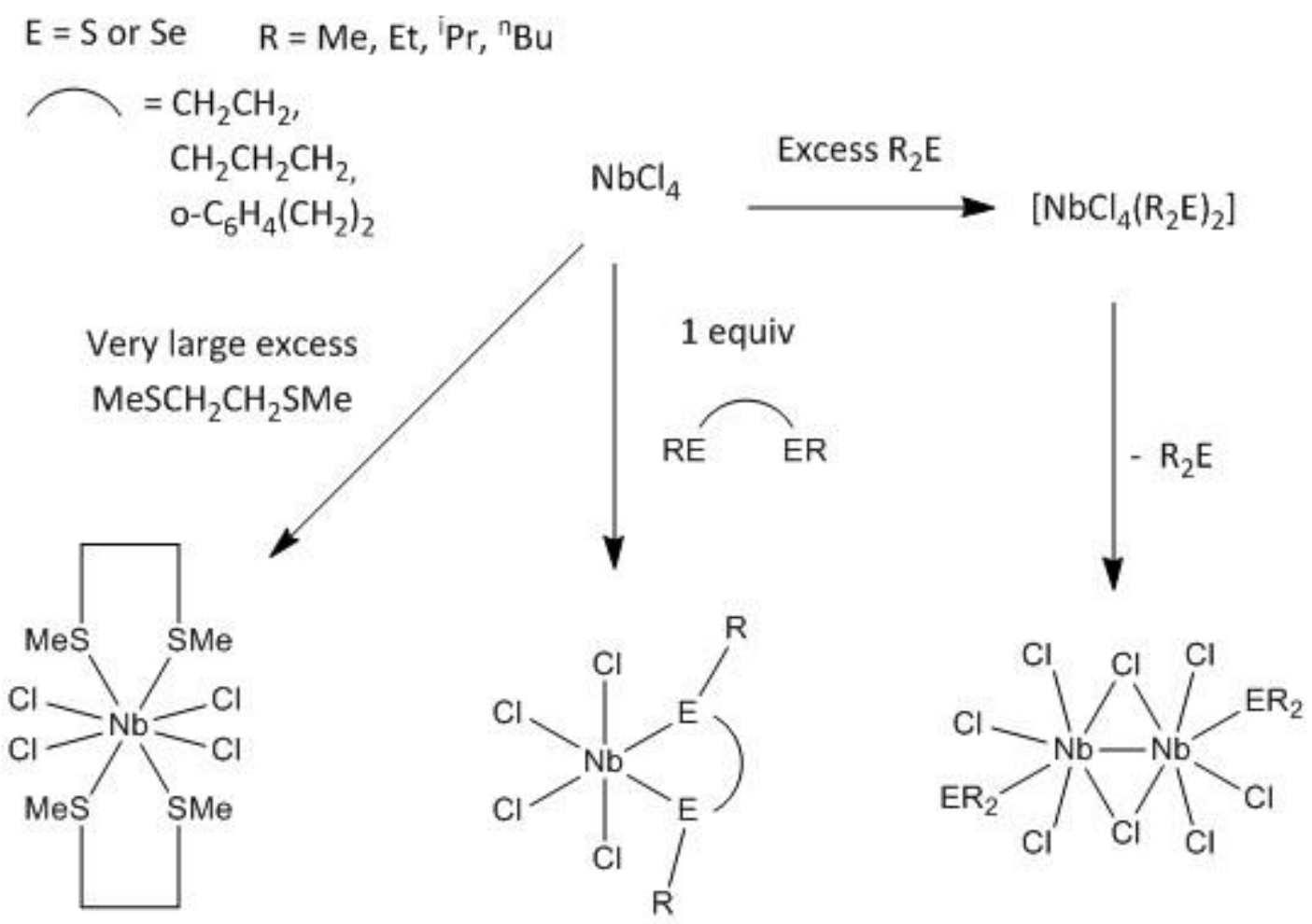

Scheme 1. Some reactions of $\mathrm{NbCl}_{4}$ with chalcogenoethers

Dithioether complexes: The reaction of a suspension of finely powdered $\mathrm{NbCl}_{4}$ with the dithioethers $\operatorname{MeS}\left(\mathrm{CH}_{2}\right)_{n} \mathrm{SMe}\left(\mathrm{n}=2\right.$ or 3), ${ }^{i} \mathrm{PrS}\left(\mathrm{CH}_{2}\right)_{2} \mathrm{~S} \operatorname{Pr}$ or $o-\mathrm{C}_{6} \mathrm{H}_{4}\left(\mathrm{CH}_{2} \mathrm{SEt}\right)_{2}$ in a 1: 1 molar ratio in either $\mathrm{CH}_{2} \mathrm{Cl}_{2}$ or toluene over several days, gave red-brown or orange solutions, from which red or brown complexes of composition $\left[\mathrm{NbCl}_{4}\right.$ (dithioether)] were isolated. Despite many attempts, an analytically pure bulk sample of $\left[\mathrm{NbCl}_{4}\left\{\mathrm{MeS}\left(\mathrm{CH}_{2}\right)_{2} \mathrm{SMe}\right\}\right]$ was not obtained, some $\left[\mathrm{NbCl}_{4}\left\{\mathrm{MeS}\left(\mathrm{CH}_{2}\right)_{2} \mathrm{SMe}\right\}_{2}\right]$ (below) always being present (microanalytical and spectroscopic evidence), which shows that the difference in stability of the two 
complexes is small. All of the complexes are very air and moisture sensitive, especially in solution, and were stored and manipulated under dry dinitrogen. Use of excess dithioether in these reactions gave only the 1:1 complexes, except in the case of $\mathrm{MeS}\left(\mathrm{CH}_{2}\right)_{2} \mathrm{SMe}$, when a large excess of ligand in toluene solution gave after workup, poor yields of brown $\left[\mathrm{NbCl}_{4}\left\{\mathrm{MeS}\left(\mathrm{CH}_{2}\right)_{2} \mathrm{SMe}\right\}_{2}\right]$. The latter is the complex described by Hamilton and McCarley, ${ }^{17}$ but the 1:1 complexes have not been identified previously. The formation of a 2:1 complex by $\mathrm{MeS}\left(\mathrm{CH}_{2}\right)_{2} \mathrm{SMe}$ alone, is similar to the formation of an eight-coordinate cation from $\mathrm{NbCl}_{5}$ in $\left[\mathrm{NbCl}_{4}\left\{\mathrm{MeS}\left(\mathrm{CH}_{2}\right)_{2} \mathrm{SMe}\right\}_{2}\right]\left[\mathrm{NbCl}_{6}\right]$, whereas all other dithioethers gave $\left[\mathrm{Cl}_{5} \mathrm{Nb}\right.$ ( $\mu$-dithioether) $\left.\mathrm{NbCl}_{5}\right]$ with six-coordinate niobium centres. ${ }^{12}$ The successful isolation of the eight-coordinate $\left[\mathrm{NbCl}_{4}\left\{\mathrm{MeS}\left(\mathrm{CH}_{2}\right)_{2} \mathrm{SMe}\right\}_{2}\right]$ probably reflects the presence of the five membered chelate ring and small steric demands of the methyl groups. We have reported elsewhere ${ }^{18}$ eight-coordinate $\left[\mathrm{NbCl}_{4}(\text { diphosphine })_{2}\right]$ complexes which also require five-membered chelate rings and small terminal groups for their formation. Red crystals of both 2,5dithiahexane complexes were grown by allowing $\mathrm{CH}_{2} \mathrm{Cl}_{2}$ solutions to evaporate under dinitrogen, and the $\mathrm{X}$ ray crystal structures are shown in Figure 1. The structure of $\left[\mathrm{NbCl}_{4}\left\{\mathrm{MeS}\left(\mathrm{CH}_{2}\right)_{2} \mathrm{SMe}\right\}_{2}\right]$ is a distorted square antiprism, similar to $\left[\mathrm{NbCl}_{4}\left\{\mathrm{Me}_{2} \mathrm{P}\left(\mathrm{CH}_{2}\right)_{2} \mathrm{PMe}_{2}\right\}_{2}\right] .{ }^{18}$ The factors which control the adoption of square antiprismatic or dodecahedral geometries in these systems are unclear, and it is probable that they differ little in energy. ${ }^{12,24}$ Both dithioether molecules have the $D L$ conformation, and the $\mathrm{Nb}$-S bond lengths in

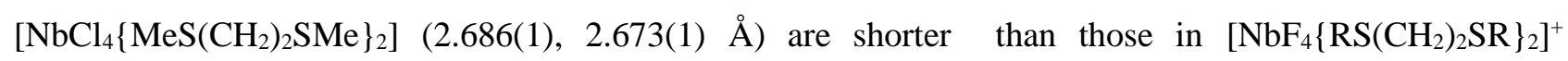
(2.704(1)-2.742(1) $\AA)^{12}$ despite the lower oxidation state, which is probably mainly attributable to the weak binding to the very hard Lewis acidic centre in the $\mathrm{Nb}(\mathrm{V})$ fluoride cations. The $\mathrm{Nb}-\mathrm{Cl}$ bond lengths (2.493(1), 2.495(1) $\AA$ ) are slightly shorter than those in $\left[\mathrm{NbCl}_{4}\left\{\mathrm{Me}_{2} \mathrm{P}\left(\mathrm{CH}_{2}\right)_{2} \mathrm{PMe}_{2}\right\}_{2}\right]$ (2.5224(8), 2.5195(8) A). ${ }^{18}$

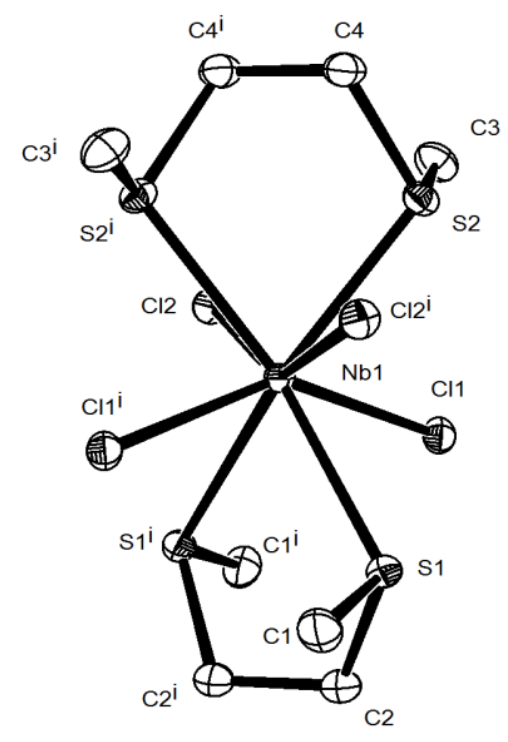

(a)

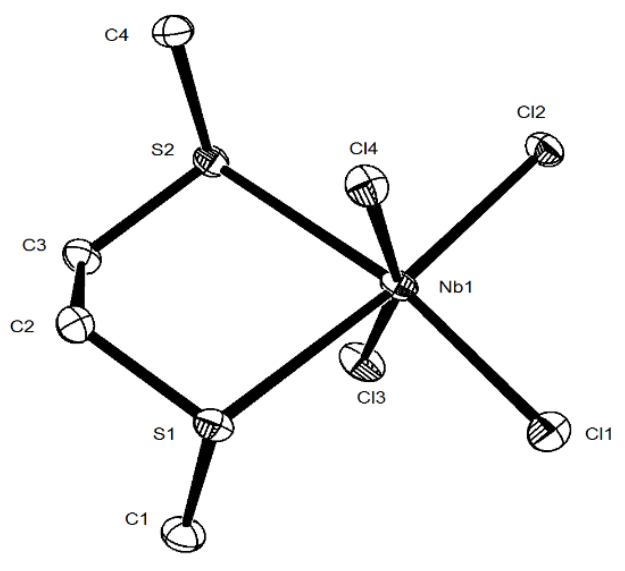

(b)

Figure 1. (a) The structure of $\left[\mathrm{NbCl}_{4}\left\{\mathrm{MeS}\left(\mathrm{CH}_{2}\right)_{2} \mathrm{SMe}\right\}_{2}\right]$ showing the atom numbering scheme and with ellipsoids drawn at the $50 \%$ probability level. Hydrogen atoms are omitted for clarity. Selected bond lengths $(\AA)$ and angles $\left(^{\circ}\right)$ : Nb1-Cl1 = 2.493(1), Nb1-Cl2 = 2.495(1), Nb-S1 = 2.686(1), Nb1-S2 = 2.6741), $\mathrm{Cl} 1-\mathrm{Nb} 1-\mathrm{Cl} 1^{\mathrm{i}}=144.78(6), \mathrm{Cl} 2-\mathrm{Nb} 1-\mathrm{Cl} 2^{\mathrm{i}}=144.58(6), \mathrm{Cl} 1-\mathrm{Nb} 1-\mathrm{Cl} 2=82.58(4), \mathrm{Cl} 1-\mathrm{Nb} 1-\mathrm{Cl} 2^{\mathrm{i}}=$ 108.26(3)), S1-Nb1-S1 ${ }^{\mathrm{i}}=76.89(5), \mathrm{S} 2-\mathrm{Nb} 1-\mathrm{S} 2^{\mathrm{i}}=76.94(5)$. Symmetry operation: $\mathrm{i}=-1+\mathrm{y}, 1+\mathrm{x},-\mathrm{z}$. 
(b) The structure of $\left[\mathrm{NbCl}_{4}\left\{\mathrm{MeS}\left(\mathrm{CH}_{2}\right)_{2} \mathrm{SMe}\right\}\right]$ showing the atom numbering scheme and with ellipsoids drawn at the $50 \%$ probability level. Hydrogen atoms are omitted for clarity. Selected bond lengths ( $\mathrm{\AA}$ ) and angles $\left({ }^{\circ}\right): \mathrm{Nb} 1-\mathrm{Cl} 1=2.333(1), \mathrm{Nb} 1-\mathrm{Cl} 2=2.359(1), \mathrm{Nb} 1-\mathrm{Cl} 3=2.330(1), \mathrm{Nb} 1-\mathrm{Cl} 4=2.340(1), \mathrm{Nb} 1-\mathrm{S} 1=$ 2.625(1), $\mathrm{Nb} 1-\mathrm{S} 2=2.652(1), \mathrm{Cl} 1-\mathrm{Nb} 1-\mathrm{Cl} 2=96.11(4), \mathrm{Cl} 3-\mathrm{Nb} 1-\mathrm{Cl} 1=97.51(4), \mathrm{Cl} 1-\mathrm{Nb} 1-\mathrm{Cl} 4=$ 95.93(4), $\mathrm{Cl} 3-\mathrm{Nb} 1-\mathrm{Cl} 2=96.03(4), \mathrm{Cl} 4-\mathrm{Nb} 1-\mathrm{Cl} 2=94.96(3), \mathrm{S} 1-\mathrm{Nb} 1-\mathrm{S} 2=81.85(3)$.

The six-coordinate $\left[\mathrm{NbCl}_{4}\left\{\mathrm{MeS}\left(\mathrm{CH}_{2}\right)_{2} \mathrm{SMe}\right\}\right]$ is a distorted octahedron with $\mathrm{Cl}-\mathrm{Nb}-\mathrm{Cl}$ angles $>90^{\circ}$,

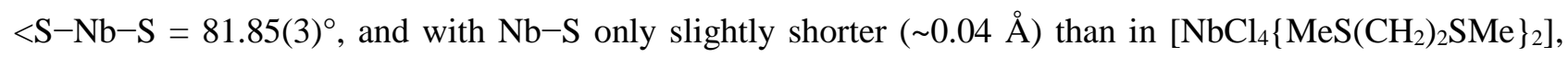
whereas the $\mathrm{Nb}-\mathrm{Cl}$ bonds are on average $\sim 0.15 \AA$ shorter, reflecting the dominant $\mathrm{Nb}-\mathrm{Cl}$ bonding and the lower coordination number. X-ray structures were also determined for $\left[\mathrm{NbCl}_{4}\left({ }^{i} \mathrm{PrS}_{(}\left(\mathrm{CH}_{2}\right)_{2} \mathrm{~S} \operatorname{Pr}\right\}\right]$, $\left[\mathrm{NbCl}_{4}\left\{\mathrm{MeS}\left(\mathrm{CH}_{2}\right)_{3} \mathrm{SMe}\right\}\right]$ and $\left[\mathrm{NbCl}_{4}\left\{o-\mathrm{C}_{6} \mathrm{H}_{4}\left(\mathrm{CH}_{2} \mathrm{SEt}\right)_{2}\right\}\right]$ which contain 5-, 6- and 7-membered chelate rings respectively (Figures 2 and 3). The changes to chelate ring-size cause progressive widening of the $\mathrm{S}-\mathrm{Nb}-\mathrm{S}$ angle $\left(81.28(4) \rightarrow 85.4(1) \rightarrow 101.50(5)^{\circ}\right)$, but the $\mathrm{Nb}-\mathrm{Cl}$ and $\mathrm{Nb}-\mathrm{S}$ distances are little different. The structure of $\left[\mathrm{NbCl}_{4}\left\{o-\mathrm{C}_{6} \mathrm{H}_{4}\left(\mathrm{CH}_{2} \mathrm{SEt}\right)_{2}\right\}\right]$ contains the ligand in the meso form, but the other three structures contain $D L$-invertomers. There is also little difference between $\mathrm{Nb}-\mathrm{Cl}_{\text {trans } \mathrm{Cl}}$ and $\mathrm{Nb}-\mathrm{Cl}_{\text {trans }}$ in these systems, and as usually observed the axial $\mathrm{Cl}-\mathrm{Nb}-\mathrm{Cl}$ angle is $<180^{\circ}$ and the unit is bent towards the neutral ligand.

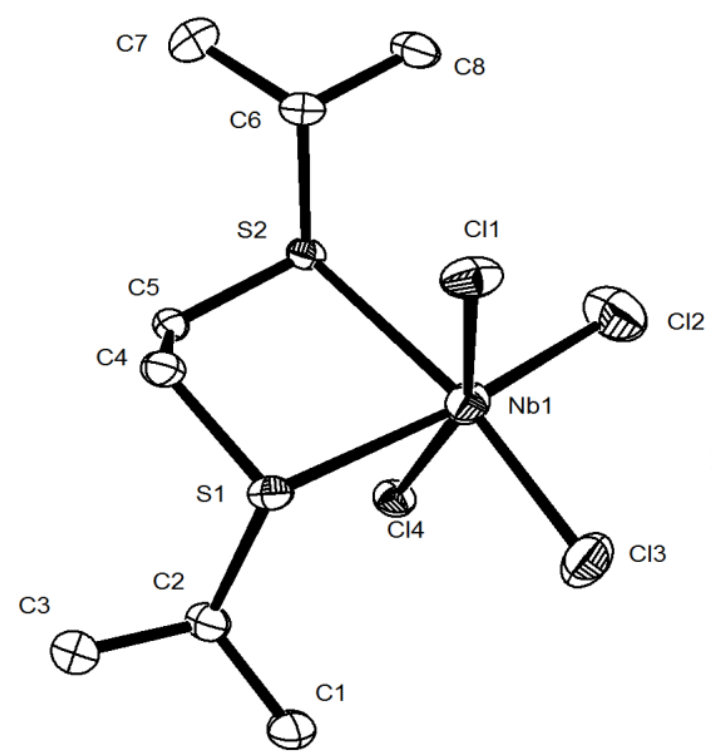

(a)

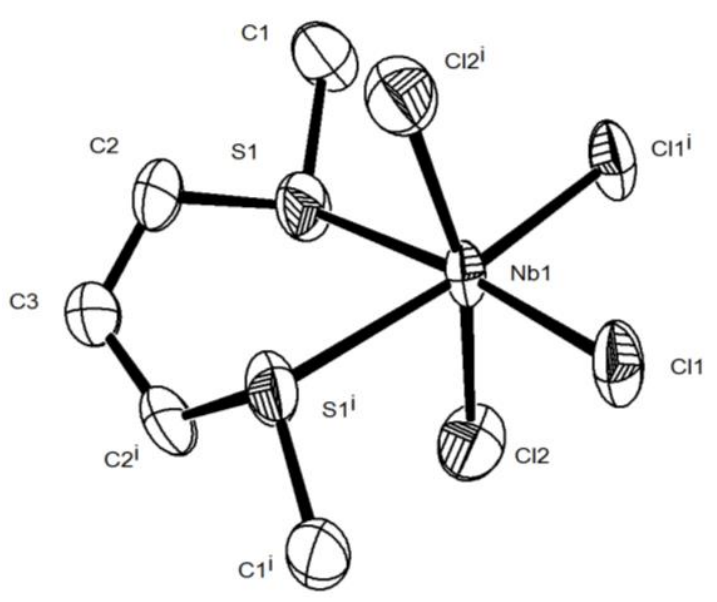

(b)

Figure 2 (a) The structure of $\left[\mathrm{NbCl}_{4}\left({ }^{i} \operatorname{PrS}\left(\mathrm{CH}_{2}\right)_{2} \mathrm{~S}\right.\right.$ Pr $\left.\}\right]$ showing the atom numbering scheme and with ellipsoids drawn at the $50 \%$ probability level. Hydrogen atoms are omitted for clarity. Selected bond lengths $(\AA)$ and angles $\left({ }^{\circ}\right)$ : Nb1-Cl1 = 2.351(2), Nb1-Cl2 = 2.250(2), Nb1-Cl3 = 2.305(2), Nb1-Cl4 = 2.341(1), $\mathrm{Nb} 1-\mathrm{S} 1=2.702(2), \mathrm{Nb} 1-\mathrm{S} 2=2.675(2), \mathrm{Cl} 2-\mathrm{Nb} 1-\mathrm{Cl} 3=94.86(8), \mathrm{Cl} 2-\mathrm{Nb} 1-\mathrm{Cl} 4=97.24(6)$, $\mathrm{Cl} 3-\mathrm{Nb} 1-\mathrm{Cl} 4=97.95(6), \mathrm{Cl} 2-\mathrm{Nb} 1-\mathrm{Cl} 1=96.72(7), \mathrm{Cl} 3-\mathrm{Nb} 1-\mathrm{Cl} 1=96.20(6), \mathrm{S} 1-\mathrm{Nb} 1-\mathrm{S} 2=81.28(4)$; (b) The structure of $\left[\mathrm{NbCl}_{4}\left\{\mathrm{MeS}\left(\mathrm{CH}_{2}\right)_{3} \mathrm{SMe}\right\}\right]$ showing the atom numbering scheme and with ellipsoids drawn at the 50\% probability level. Hydrogen atoms are omitted for clarity. Selected bond lengths $(\AA)$ and angles $\left({ }^{\circ}\right): \mathrm{Nb} 1-\mathrm{Cl} 1=2.349(3), \mathrm{Nb} 1-\mathrm{Cl} 2=2.332(4), \mathrm{Nb} 1-\mathrm{S} 1=2.630(3), \mathrm{Cl} 2-\mathrm{Nb} 1-\mathrm{Cl} 1=97.8(2)$, $\mathrm{Cl} 2-\mathrm{Nb} 1-\mathrm{Cl} 1^{\mathrm{i}}=97.2(2), \mathrm{Cl1}-\mathrm{Nb} 1-\mathrm{Cl} 1^{\mathrm{i}}=94.1(2), \mathrm{S} 1-\mathrm{Nb} 1-\mathrm{S} 1^{\mathrm{i}}=85.4(2)$. Symmetry operation: $\mathrm{i}=-\mathrm{x}, 1-\mathrm{y}$, $\mathrm{z}$. 


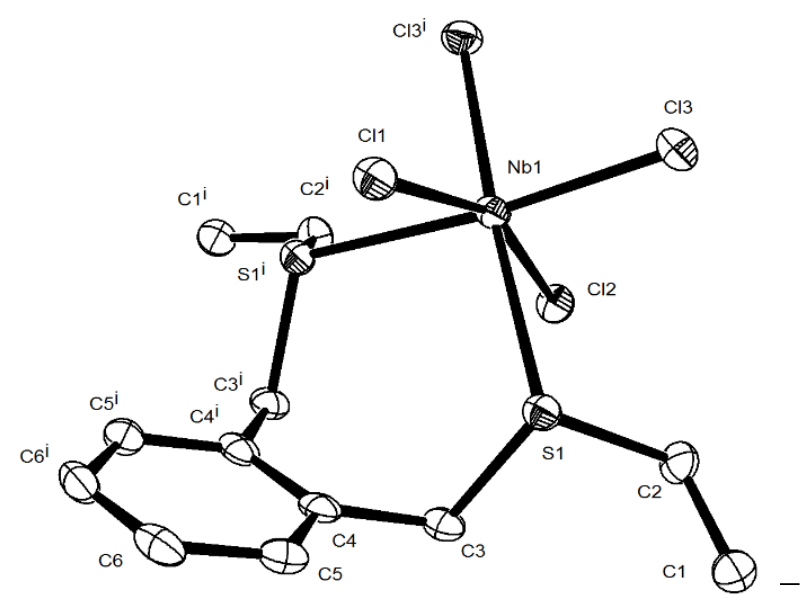

Figure 3. The structure of $\left[\mathrm{NbCl}_{4}\left\{o-\mathrm{C}_{6} \mathrm{H}_{4}\left(\mathrm{CH}_{2} \mathrm{SEt}\right)_{2}\right\}\right]$ showing the atom numbering scheme and with ellipsoids drawn at the $50 \%$ probability level. Hydrogen atoms are omitted for clarity. Selected bond lengths $(\AA)$ and angles $\left({ }^{\circ}\right)$ : Nb1-Cl1 = 2.331(2), Nb1-Cl2 = 2.327(1), Nb1-Cl3 = 2.376(1), Nb1-S1 = 2.652(1), $\mathrm{Cl} 2-\mathrm{Nb} 1-\mathrm{Cl} 3=98.77(4), \mathrm{Cl} 1-\mathrm{Nb} 1-\mathrm{Cl} 3=97.07(4), \mathrm{Cl} 3-\mathrm{Nb} 1-\mathrm{Cl}^{\mathrm{i}}=92.05(5), \mathrm{S} 1-\mathrm{Nb} 1-\mathrm{S} 1^{\mathrm{i}}=101.5(5)$. Symmetry operation: $\mathrm{i}=\mathrm{x}, 1 / 2-\mathrm{y}, \mathrm{z}$.

The six- and eight-coordinate complexes are also distinguished by the $\mathrm{Nb}-\mathrm{Cl}$ stretches in the far IR spectra, where the former exhibit bands in the range $\sim 360-320 \mathrm{~cm}^{-1}$ and the latter shows two bands at 305 and 282 $\mathrm{cm}^{-1}$. The markedly lower frequency observed in the eight-coordinate complex was also observed in $\left[\mathrm{MCl}_{4}\left\{\mathrm{MeS}\left(\mathrm{CH}_{2}\right)_{2} \mathrm{SMe}_{2}\right](\mathrm{M}=\mathrm{Zr} \text { or } \mathrm{Hf})^{24}\right.$ and is a characteristic fingerprint of the higher coordination number. The UV/visible spectra of the solids show strong absorptions $>\sim 25000 \mathrm{~cm}^{-1}$, which may be assigned as $\mathrm{S}(\pi) \rightarrow \mathrm{Nb}$ and $\mathrm{Cl}(\pi) \rightarrow \mathrm{Nb}$ charge transfer transitions, with much weaker and rather ill-defined bands at lower energy in the tails of the CT transitions, assignable to d-d transitions. ${ }^{15-18}$ Distinction of 6- or 8-coordination on the basis of the UV/visible spectra is uncertain since the charge transfer transition energies are expected to be little different, ${ }^{24}$ and the d-d spectra are insufficiently well defined. Many of the complexes are partially dissociated in solution, so solution data are unreliable and not reported. As expected for paramagnetic systems, ${ }^{1} \mathrm{H}$ NMR spectra showed only small amounts of uncoordinated chalcogenether, either due to dissociation or trace hydrolysis. Both types of complex have magnetic moments at ambient temperatures consistent with mononuclear $\mathrm{d}^{1}$ systems $-\mu_{\mathrm{B}}=1.63$ B.M. for $\left[\mathrm{NbCl}_{4}\left\{\mathrm{MeS}\left(\mathrm{CH}_{2}\right)_{2} \mathrm{SMe}\right\}_{2}\right]^{17}$ and $\mu_{\mathrm{B}}=1.69$ B.M. for $\left[\mathrm{NbCl}_{4}\left(\mathrm{PrS}\left(\mathrm{CH}_{2}\right)_{2} \mathrm{~S} \operatorname{Pr}\right\}\right]$.

Diselenoether complexes: The reactions of $\mathrm{NbCl}_{4}$ with $\mathrm{MeSe}\left(\mathrm{CH}_{2}\right)_{n} \mathrm{SeMe}(\mathrm{n}=2,3)$ or ${ }^{\mathrm{n}} \mathrm{BuSe}\left(\mathrm{CH}_{2}\right)_{3} \mathrm{Se}{ }^{\mathrm{n}} \mathrm{Bu}$ in $\mathrm{CH}_{2} \mathrm{Cl}_{2}$ gave modest yields of the six-coordinate $\left[\mathrm{NbCl}_{4}\left\{\mathrm{RSe}\left(\mathrm{CH}_{2}\right)_{n} \mathrm{SeR}\right\}\right]$, confirmed by the X-ray crystal structure of $\left[\mathrm{NbCl}_{4}\left\{\mathrm{MeSe}\left(\mathrm{CH}_{2}\right)_{3} \mathrm{SeMe}\right\}\right]$ (Figure 4). The ligand 2,5-diselahexane does not appear to form an eight coordinate $\left[\mathrm{NbCl}_{4}\left\{\mathrm{MeSe}\left(\mathrm{CH}_{2}\right)_{2} \mathrm{SeMe}\right\}_{2}\right]$ corresponding to the 2,5-dithiahexane complex described above. Using a large excess of $\mathrm{MeSe}\left(\mathrm{CH}_{2}\right)_{2} \mathrm{SeMe}$ in the synthesis led only to isolation of the six-coordinate complex and some decomposition of the diselenahexane. Using $o-\mathrm{C}_{6} \mathrm{H}_{4}\left(\mathrm{CH}_{2} \mathrm{SeMe}\right)_{2}$ in these reactions led to fragmentation of the diselenoether as described below. 


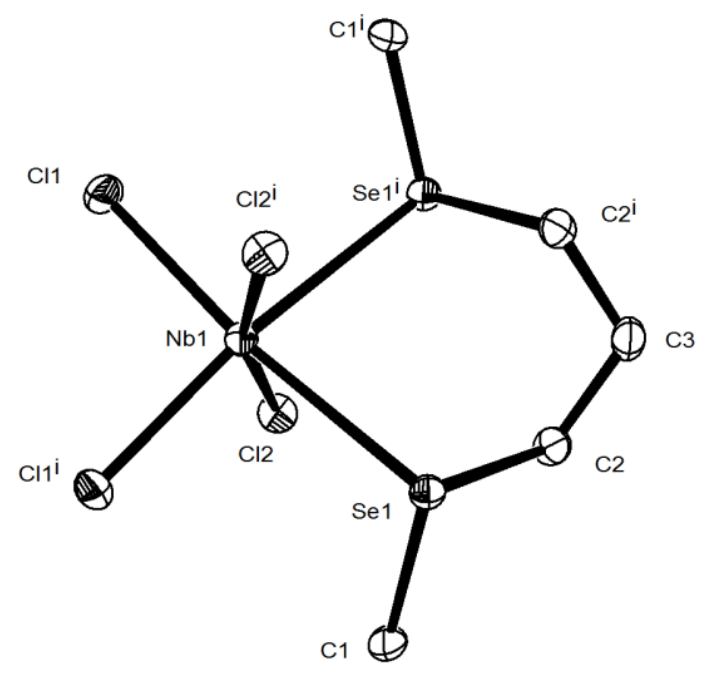

Figure 4. The structure of $\left[\mathrm{NbCl}_{4}\left\{\mathrm{MeSe}\left(\mathrm{CH}_{2}\right)_{3} \mathrm{SeMe}\right\}\right]$ showing the atom numbering scheme and with ellipsoids drawn at the $50 \%$ probability level. Hydrogen atoms are omitted for clarity. Selected bond lengths $(\AA)$ and angles $\left(^{\circ}\right)$ : Nb1-Cl1 = 2.360(1), Nb1-Cl2 = 2.339(1), Nb1-Se1 = 2.7648(7), Cl2-Nb1-Cl1 = 97.67(4), Cl2-Nb1-Cl1 ${ }^{\mathrm{i}}=93.49(4), \mathrm{Cl} 1-\mathrm{Nb}-\mathrm{Cl} 1^{\mathrm{i}}=95.39(7), \mathrm{Se} 1-\mathrm{Nb} 1-\mathrm{Se} 1^{\mathrm{i}}=84.07(3)$. Symmetry operation: $\mathrm{i}=1-\mathrm{x}, 1.5-\mathrm{y}, \mathrm{z}$.

Ditelluroether complexes. Most attempts to isolate complexes with ditelluroethers were unsuccessful, giving very poor yields, and often evidence of $\mathrm{C}-\mathrm{Te}$ cleavage. However, $\left[\mathrm{NbCl}_{4}\left[{ }^{\mathrm{t}} \mathrm{BuTe}\left(\mathrm{CH}_{2}\right)_{3} \mathrm{Te}^{\mathrm{t}} \mathrm{Bu}\right\}_{2}\right]$ was isolated as a dark solid, presumably containing eight-coordinate niobium, although attempts to obtain crystals failed.

$\mathbf{R}_{2} \mathbf{E}\left(\mathbf{E}=\mathbf{S}\right.$, Se or Te) Complexes: The $\mathrm{NbCl}_{4}$ complexes with monodentate chalcogenoethers are very sensitive to moisture and appear partially dissociated in solution in $\mathrm{CH}_{2} \mathrm{Cl}_{2}$. Complexes with both 1:1 and 1:2 $\mathrm{NbCl}_{4}: \mathrm{R}_{2} \mathrm{E}$ stoichiometries have been isolated with some ligands, and these appear to be in equilibrium in non-donor solvents. The reaction of $\mathrm{NbCl}_{4}$ with a large excess of $\mathrm{Me}_{2} \mathrm{~S}$ in $\mathrm{CH}_{2} \mathrm{Cl}_{2}$ solution gave after careful removal of excess $\mathrm{Me}_{2} \mathrm{~S}$ and solvent in vacuo at $0^{\circ} \mathrm{C}$, a red-purple paramagnetic solid. It is probably cis$\left[\mathrm{NbCl}_{4}\left(\mathrm{Me}_{2} \mathrm{~S}\right)_{2}\right]$ since the pattern of $v(\mathrm{Nb}-\mathrm{Cl})$ in the far IR spectrum is similar to those of the cis$\left[\mathrm{NbCl}_{4}\left\{\mathrm{RS}\left(\mathrm{CH}_{2}\right)_{2} \mathrm{SR}\right\}\right] .{ }^{17}$ It loses $\mathrm{Me}_{2} \mathrm{~S}$ readily in vacuo, on standing in the solid state, or in solution, and yellow-brown crystals deposited from the solution in $\mathrm{CH}_{2} \mathrm{Cl}_{2}$ were found to be the 1:1 complex. The latter was isolated in modest yield by layering a solution of $\mathrm{NbCl}_{4}$ with a smaller excess of $\mathrm{Me}_{2} \mathrm{~S}$ in $\mathrm{CH}_{2} \mathrm{Cl}_{2}$, with n-hexane. The structure (Figure 5) shows it to be $\left[\mathrm{Nb}_{2} \mathrm{Cl} 6(\mu-\mathrm{Cl})_{2}\left(\mathrm{Me}_{2} \mathrm{~S}\right)_{2}\right]$, an $\mathrm{Nb}_{2}{ }^{8+}$ species with a single $\left(\sigma^{2}\right)$ $\mathrm{Nb}-\mathrm{Nb}$ bond. It is isomorphous with $\left[\mathrm{Ta}_{2} \mathrm{Cl}_{6}(\mu-\mathrm{Cl})_{2}\left(\mathrm{Me}_{2} \mathrm{~S}\right)_{2}\right]$ which we obtained as an "under-reduced" byproduct of the synthesis of the $\mathrm{Ta}_{2}{ }^{6+}$ complex $\left[\mathrm{Ta}_{2} \mathrm{Cl}_{4}(\mu-\mathrm{Cl})_{2}\left(\mathrm{Me}_{2} \mathrm{~S}\right)_{2}\right]$ from $\mathrm{TaCl}_{5}, \mathrm{Mg}$ and $\mathrm{Me}_{2} \mathrm{~S}$. ${ }^{11}$ The $\mathrm{Nb}-\mathrm{Nb}$ bond length of 3.1094(5) $\AA$ is very similar to other niobium single bonds and confirms the $\mathrm{Nb}$ (IV) oxidation state. ${ }^{11,14}$ 


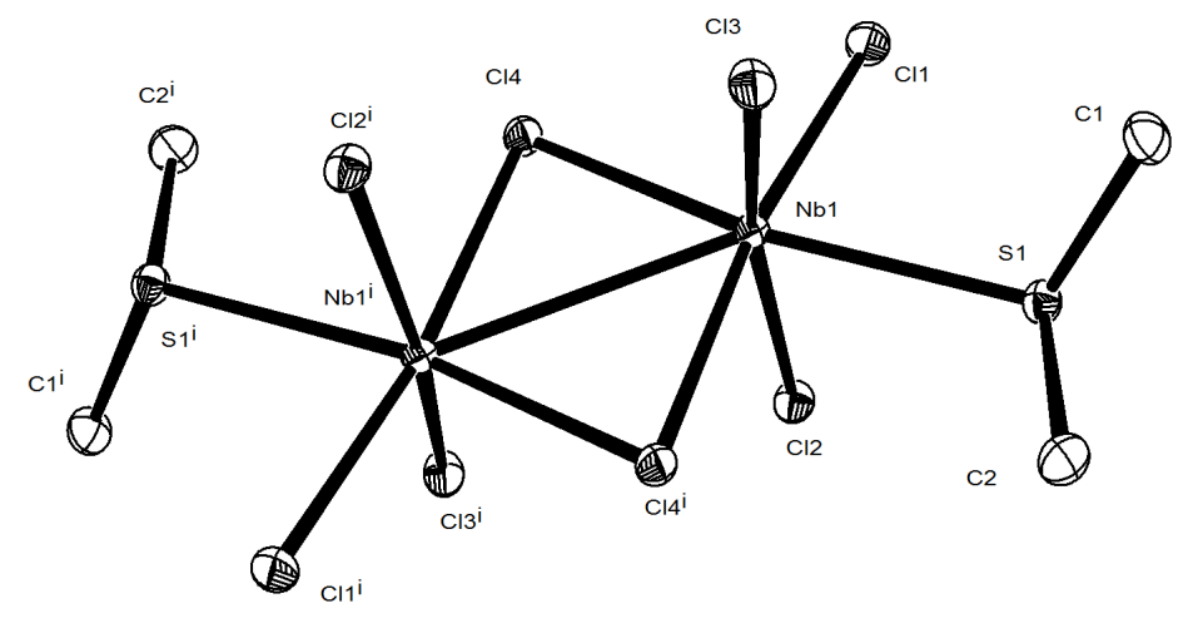

Figure 5 The structure of $\left[\mathrm{Nb}_{2} \mathrm{Cl}_{8}\left(\mathrm{Me}_{2} \mathrm{~S}\right)_{2}\right]$ showing the atom numbering scheme and with ellipsoids drawn at the 50\% probability level. Hydrogen atoms are omitted for clarity. Selected bond lengths $(\AA)$ and angles $\left(^{\circ}\right)$ : $\mathrm{Nb} 1-\mathrm{Cl} 1=2.3768(7), \mathrm{Nb} 1-\mathrm{Cl} 2=2.3110(6), \mathrm{Nb} 1-\mathrm{Cl} 3=2.3149(6), \mathrm{Nb} 1-\mathrm{Cl} 4=2.4205(6), \mathrm{Nb} 1-\mathrm{Cl} 4^{\mathrm{i}}=$ $2.5107(6), \mathrm{Nb} 1-\mathrm{Nb} 1^{\mathrm{i}}=3.1094(5), \mathrm{Nb} 1-\mathrm{S} 1=2.6207(7) ; \mathrm{Cl} 1-\mathrm{Nb} 1-\mathrm{Cl} 4^{\mathrm{i}}=171.68(2), \mathrm{Cl} 2-\mathrm{Nb} 1-\mathrm{Cl} 3$ $=163.19(3), \mathrm{Cl} 4-\mathrm{Nb} 1-\mathrm{Cl} 4^{\mathrm{i}}=101.84(2), \mathrm{Cl} 2-\mathrm{Nb} 1-\mathrm{Cl1}=92.93(2), \mathrm{Cl} 1-\mathrm{Nb} 1-\mathrm{Cl} 3=94.50(2), \mathrm{Cl} 2-\mathrm{Nb} 1-\mathrm{Cl} 4$ $=98.03(2), \mathrm{Cl} 1-\mathrm{Nb} 1-\mathrm{Cl} 4=83.32(2), \mathrm{Cl} 3-\mathrm{Nb} 1-\mathrm{Cl} 4^{\mathrm{i}}=85.82(2), \mathrm{Nb} 1-\mathrm{Cl} 1-\mathrm{Nb} 1^{\mathrm{i}}=78.16(2)$. Symmetry operation: $\mathrm{i}=\mathrm{x}+2,-\mathrm{y}, \mathrm{z}+1$.

Two selenoether complexes, $\left[\mathrm{NbCl}_{4}\left(\mathrm{R}_{2} \mathrm{Se}\right)_{2}\right]\left(\mathrm{R}=\mathrm{Me}\right.$ or $\left.{ }^{\mathrm{n}} \mathrm{Bu}\right)$, were also isolated and proved somewhat more stable than the $\mathrm{Me}_{2} \mathrm{~S}$ complex. Both had satisfactory microanalyses, and the $\left[\mathrm{NbCl}_{4}\left({ }^{\mathrm{n}} \mathrm{Bu}_{2} \mathrm{Se}\right)_{2}\right]$ was spectroscopically similar to the $\left[\mathrm{NbCl}_{4}\right.$ (diselenoether)] adducts described above, suggesting a cis-octahedral structure. The far IR spectrum of $\left[\mathrm{NbCl}_{4}\left(\mathrm{Me}_{2} \mathrm{Se}\right)_{2}\right]$ had $v(\mathrm{Nb}-\mathrm{Cl})=341,314,286,255 \mathrm{~cm}^{-1}$, significantly lower frequencies than in six-coordinate examples, suggesting it may contain eight-coordinate $\mathrm{Nb}$ in a dimer structure (see below). The measured magnetic moment at $295 \mathrm{~K}$ is $\mu_{\mathrm{B}}=1.15 \mathrm{~B} . \mathrm{M}$., which is difficult to rationalise, but is in the range reported by Hamilton and McCarley ${ }^{15}$ for $\left[\mathrm{NbX}_{4}\left(\mathrm{Me}_{2} \mathrm{~S}\right)_{2}\right](\mathrm{X}=\mathrm{Br}$ or I) and $\left[\mathrm{NbX}_{4}(\text { tht })_{2}\right](\mathrm{X}=\mathrm{Cl}, \mathrm{Br}$ or $\mathrm{I}$; tht $=$ tetrahydrothiophene $)$. Attempts to grow crystals of $\left[\mathrm{NbCl}_{4}\left(\mathrm{Me}_{2} \mathrm{Se}\right)_{2}\right]$ were unsuccessful, since on standing in $\mathrm{CH}_{2} \mathrm{Cl}_{2}$ solution, yellowish crystals of $\left[\mathrm{Nb}_{2} \mathrm{Cl}_{8}\left(\mathrm{Me}_{2} \mathrm{Se}\right)_{2}\right]$ (Figure 6) were deposited. Although the crystals are not isomorphous with those of the $\mathrm{Me}_{2} \mathrm{~S}$ analogue, the structures are very similar. The solid $\left[\mathrm{Nb}_{2} \mathrm{Cl}_{8}\left(\mathrm{Me}_{2} \mathrm{E}\right)_{2}\right]$ are diamagnetic with a small TIP component of $\leq 0.5 \mathrm{~B} \cdot \mathrm{M}^{15,16}$

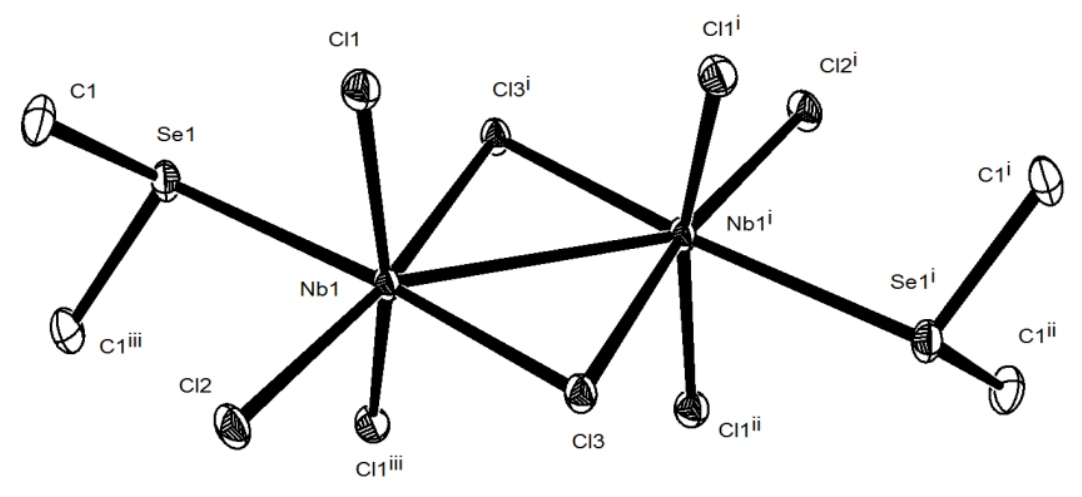

Figure 6 The structure of $\left[\mathrm{Nb}_{2} \mathrm{Cl}_{8}\left(\mathrm{Me}_{2} \mathrm{Se}\right)_{2}\right]$ showing the atom numbering scheme and with ellipsoids drawn at the $50 \%$ probability level. Hydrogen atoms are omitted for clarity. Selected bond lengths ( $\AA$ ) and angles 
$\left({ }^{\circ}\right): \mathrm{Nb} 1-\mathrm{Cl} 1=2.297(1), \mathrm{Nb} 1-\mathrm{Cl} 2=2.385(1), \mathrm{Nb} 1-\mathrm{Cl} 3=2.405(1), \mathrm{Nb} 1-\mathrm{Nb} 1^{\mathrm{i}}=3.0524(9), \mathrm{Nb} 1-\mathrm{Se} 1=$ 2.7518(8); $\mathrm{Cl} 1-\mathrm{Nb} 1-\mathrm{Cl} 1^{\mathrm{iii}}=163.98(6), \mathrm{Cl} 2-\mathrm{Nb} 1-\mathrm{Cl} 3=87.32(5), \mathrm{Cl} 2-\mathrm{Nb} 1-\mathrm{Se} 1=87.40(4), \mathrm{Se} 1-\mathrm{Nb} 1-\mathrm{Cl} 3^{\mathrm{i}}$ $=82.77(3), \mathrm{Nb} 1-\mathrm{Cl} 3-\mathrm{Nb} 1^{\mathrm{i}}=77.49(4) \mathrm{Cl} 3-\mathrm{Nb} 1-\mathrm{Cl}^{\mathrm{i}}=102.51(4)$. Symmetry operation: $\mathrm{i}=\mathrm{x},-\mathrm{y}, 1-\mathrm{z} ; \mathrm{ii}=$ $1-\mathrm{x},-\mathrm{y}, 1-\mathrm{z}$; iii $=1-\mathrm{x}, \mathrm{y}, \mathrm{z}$.

Although a very unstable purple $\left[\mathrm{NbCl}_{5}\left(\mathrm{Me}_{2} \mathrm{Te}\right)\right]$ is known, ${ }^{12,25}$ (and the more robust $\left[\mathrm{TaCl}_{5}\left(\mathrm{Me}_{2} \mathrm{Te}\right)\right]$ has been crystallographically characterised ${ }^{10}$ ), initial attempts to form an $\mathrm{Me}_{2} \mathrm{Te}$ complex of $\mathrm{NbCl}_{4}$ under a variety of conditions resulted in decomposition. By conducting the reaction of $\mathrm{NbCl}_{4}$ with $\mathrm{Me}_{2} \mathrm{Te}$ in $\mathrm{CH}_{2} \mathrm{Cl}_{2}$ for 3 days at room temperature as described in the Experimental section, a brown complex with a 2:1 $\mathrm{Me}_{2} \mathrm{Te}$ : $\mathrm{NbCl}_{4}$ composition was obtained, and red crystals were grown by allowing a $\mathrm{CH}_{2} \mathrm{Cl}_{2}$ solution of the complex to evaporate under a $\mathrm{N}_{2}$ atmosphere. However, rather than the cis-[ $\left[\mathrm{NbCl}_{4}\left(\mathrm{Me}_{2} \mathrm{Te}\right)_{2}\right]$ structure expected, these proved to be of a dimer with eight-coordinate niobium, $\left[\mathrm{Nb}_{2} \mathrm{Cl}_{8}\left(\mathrm{Me}_{2} \mathrm{Te}\right)_{4}\right]$ (Figure 7). The structure is similar to that of $\left[\mathrm{Nb}_{2} \mathrm{Cl}_{4}(\mu-\mathrm{Cl})_{4}(\mathrm{PMe} 2 \mathrm{Ph})_{4}\right],{ }^{23}$ with a square $\mathrm{Cl}_{4}$ face linking the $\mathrm{Nb}$ centres.

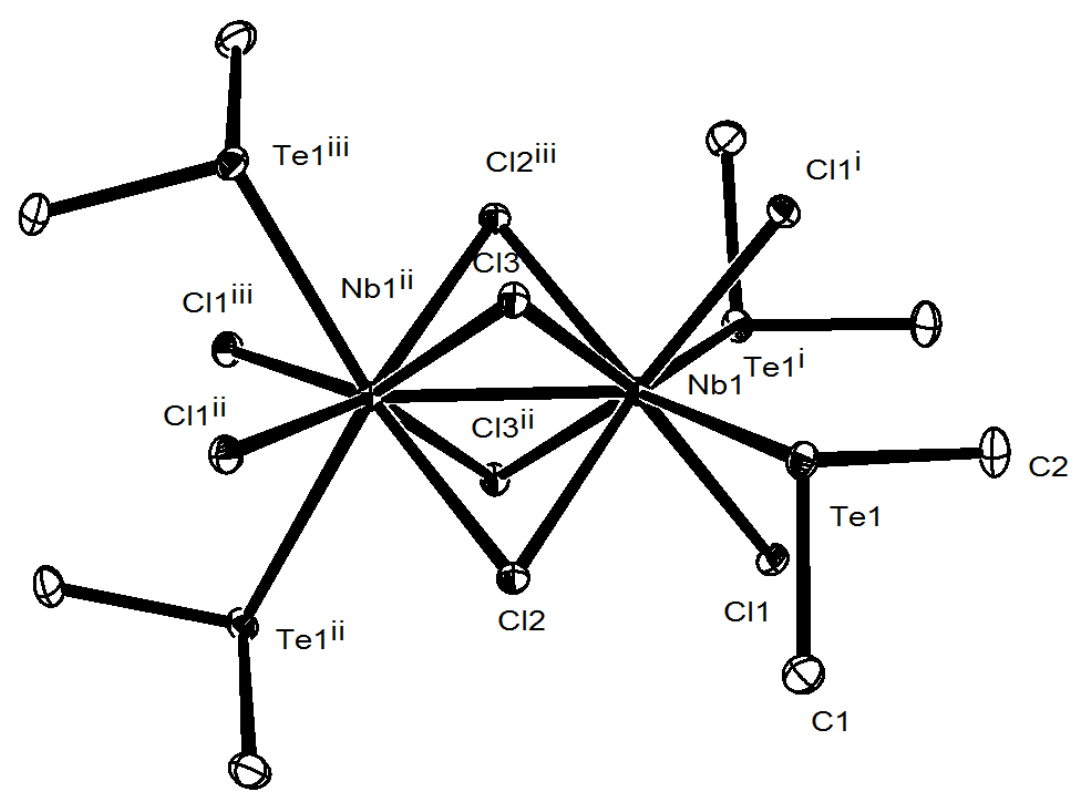

Figure 7. The structure of $\left[\mathrm{Nb}_{2} \mathrm{Cl}_{8}\left(\mathrm{Me}_{2} \mathrm{Te}\right)_{4}\right]$ showing the atom numbering scheme and with ellipsoids drawn at the $50 \%$ probability level. Hydrogen atoms are omitted for clarity. Selected bond lengths $(\AA)$ and angles $\left({ }^{\circ}\right): \mathrm{Nb} 1-\mathrm{Cl} 1=2.4922(8), \mathrm{Nb} 1-\mathrm{Cl} 2=2.5548(9), \mathrm{Nb} 1-\mathrm{Cl} 3=2.5445(9), \mathrm{Nb} 1-\mathrm{Nb} 1^{\mathrm{ii}}=2.8208(8), \mathrm{Nb} 1-\mathrm{Te} 1=$ 2.9591(3); $\mathrm{Cl} 1-\mathrm{Nb} 1-\mathrm{Cl} 1^{\mathrm{i}}=105.14(4), \mathrm{Cl} 2-\mathrm{Nb} 1-\mathrm{Cl} 2^{\mathrm{iii}}=112.99(3), \mathrm{Cl} 3-\mathrm{Nb} 1-\mathrm{Cl} 3^{\mathrm{ii}}=112.68(3)$. Symmetry operation: $\mathrm{i}=-\mathrm{y}+1,-\mathrm{x}+1,-\mathrm{z}+2$, ii $=-\mathrm{x}+1,-\mathrm{y}+1, \mathrm{z}$, iii $=\mathrm{y}, \mathrm{x},-\mathrm{z}+2$.

The $\mathrm{Nb}-\mathrm{Nb}$ bond length of $2.8208(8) \AA$ is very similar to that of the phosphine analogue. ${ }^{23}$ The far IR spectrum is similar to that described above for $\left[\mathrm{NbCl}_{4}\left(\mathrm{Me}_{2} \mathrm{Se}\right)_{2}\right]$ with $v(\mathrm{Nb}-\mathrm{Cl})=358 \mathrm{w}, 326 \mathrm{br}, 276,250 \mathrm{w}$ $\mathrm{cm}^{-1}$ ). Unfortunately, insufficient sample could be obtained to perform a reliable magnetic measurement.

Ligand Fragmentation Reactions: As previously noted in investigations of the $\mathrm{Nb}_{2}{ }^{6+}$ dimer chemistry, ${ }^{11,14}$ chalcogenoether ligands can undergo $\mathrm{C}-\mathrm{E}$ bond fission in some reactions and the products may contain sulfide or selenide ligands or $\mathrm{RE}^{-}$groups. Since the isoelectronic $\mathrm{Cl}^{-}$and $\mathrm{S}^{2-}$ ligands are very difficult to distinguish by X-ray crystallography, some erroneous complexes have been reported. ${ }^{1,14}$ In some reactions carried out in the present study, in addition to the complexes described above, minor amounts of other 
products, often of different colours were observed. Most remain unidentified, but two products merit mention and illustrate these effects. A suspension of $\mathrm{NbCl}_{4}$ in $\mathrm{CH}_{2} \mathrm{Cl}_{2}$ containing $\mathrm{MeS}\left(\mathrm{CH}_{2}\right)_{3} \mathrm{SMe}$ left undisturbed in a sealed vessel for 6 weeks, deposited red crystals of $\left[\mathrm{NbCl}_{4}\left\{\mathrm{MeS}\left(\mathrm{CH}_{2}\right)_{3} \mathrm{SMe}\right\}\right]$ (above) and a few yellow crystals, which were identified on structure solution as the sulfide-bridged $\mathrm{Nb}(\mathrm{IV})$ dimer $\left[\mathrm{Nb}_{2} \mathrm{Cl}_{4}(\mu-\right.$ $\left.\mathrm{S})_{2}\left\{\mathrm{MeS}\left(\mathrm{CH}_{2}\right)_{3} \mathrm{SMe}\right\}_{2}\right]$, (Figure 8). The $\mathrm{Nb}-\mathrm{Nb}=2.881$ (1) $\AA$, consistent with a single bond, identifies the metal oxidation state and confirms that the bridging ligands are sulfidel, not chloride. ${ }^{14}$ The complex is an analogue of the $\mathrm{Ta}(\mathrm{IV})$ species $\left[\mathrm{Ta}_{2} \mathrm{Cl}_{4}(\mu-\mathrm{S})_{2}\left(\mathrm{EtSCH}_{2} \mathrm{CH}_{2} \mathrm{SEt}\right)_{2}\right] .{ }^{14}$

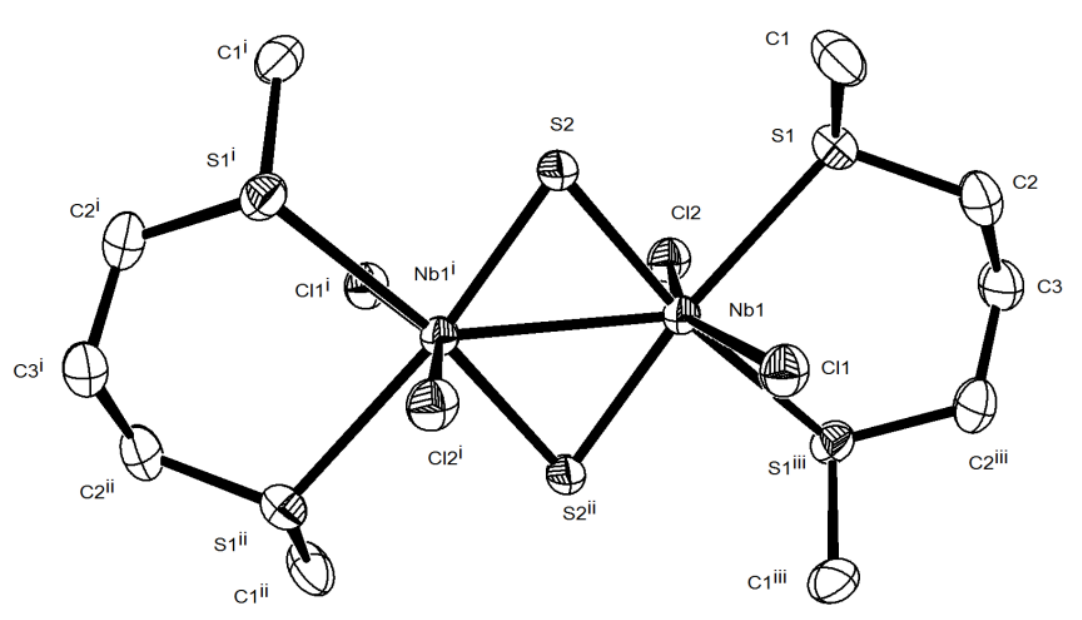

Figure 8. The structure of $\left[\mathrm{Nb}_{2} \mathrm{Cl}_{4}(\mu-\mathrm{S})_{2}\left\{\mathrm{MeS}\left(\mathrm{CH}_{2}\right)_{3} \mathrm{SMe}\right\}_{2}\right]$ showing the atom numbering scheme and with ellipsoids drawn at the $50 \%$ probability level. Hydrogen atoms are omitted for clarity. Selected bond lengths $(\AA)$ and angles $\left({ }^{\circ}\right)$ : Nb1-Cl1 $=2.375(1), \mathrm{Nb} 1-\mathrm{Cl} 2=2.382(1), \mathrm{Nb} 1-\mathrm{S} 1=2.677(1), \mathrm{Nb} 1-\mathrm{Nb} 1^{\mathrm{i}}=2.882(1)$, $\mathrm{C} 11-\mathrm{Nb} 1-\mathrm{Cl} 2=155.60(6), \mathrm{S} 1-\mathrm{Nb} 1-\mathrm{S} 1^{\mathrm{iii}}=87.28(5), \mathrm{S} 2-\mathrm{Nb} 1-\mathrm{S} 2^{\mathrm{i}}=104.33(4)$. Symmetry operation: $\mathrm{i}=1-$ $\mathrm{x}, 1-\mathrm{y}, \mathrm{z} ; \mathrm{ii}=1-\mathrm{x}, 1-\mathrm{y},-\mathrm{z} ;$ iii $=\mathrm{x}, \mathrm{y},-\mathrm{z}$.

The reaction of $\mathrm{NbCl}_{4}$ in $\mathrm{CH}_{2} \mathrm{Cl}_{2}$ with the diselenoether, $o-\mathrm{C}_{6} \mathrm{H}_{4}\left(\mathrm{CH}_{2} \mathrm{SeMe}\right)_{2}$, gave a brown diamagnetic product in modest yield. The ${ }^{1} \mathrm{H}$ and ${ }^{13} \mathrm{C}\left\{{ }^{1} \mathrm{H}\right\}$ NMR spectra of this solid showed the presence of $\mathrm{CH}_{2} \mathrm{Se}$, and the aromatic backbone, but no SeMe resonances, and did not show significant amounts of other niobium species. Crystals grown from this product showed the presence of 1,3-dihydro-benzo[c]selenophane ( $o$ $\mathrm{C}_{6} \mathrm{H}_{4}\left(\mathrm{CH}_{2}\right)_{2} \mathrm{Se}$ ) (Figure 9a) ${ }^{26}$ coordinated to a $\mathrm{Nb}$ dimer with selenium bridges (Figure 10). There are some difficulties with the interpretation of the electron density peaks pertaining to the bridging Se positions, although it is clear that the major species comprises two $\mu^{2}$-Se bridges in $\left[\mathrm{Nb}_{2} \mathrm{Cl}_{4}(\mu-\mathrm{Se})_{2}\left\{o-\mathrm{C}_{6} \mathrm{H}_{4}\left(\mathrm{CH}_{2}\right)_{2} \mathrm{Se}\right\}_{4}\right]$. However, a minor component shows a diselenide bridging unit - the details are presented in the ESI. Fragmentation of this ligand has been seen in other systems ${ }^{27,28}$ and reaction with $\left[\mathrm{Ta}_{2} \mathrm{Cl}_{4}\left(\mathrm{Me}_{2} \mathrm{~S}\right)_{2}(\mu-\mathrm{Cl})_{2}(\mu-\right.$ $\left.\left.\mathrm{Me}_{2} \mathrm{~S}\right)\right]$ gave a mixture of products, including $\left[\mathrm{Ta}_{2} \mathrm{Cl}_{4}\left\{o-\mathrm{C}_{6} \mathrm{H}_{4}\left(\mathrm{CH}_{2} \mathrm{SeMe}\right)_{2}\right\}_{2}(\mu-\mathrm{Se})_{2}\right]$ (Figure 9b), ${ }^{11}$ although with $\mathrm{NbCl}_{5}$ the product was the simple adduct $\left[\mathrm{Cl}_{5} \mathrm{Nb}\left\{\mu-o-\mathrm{C}_{6} \mathrm{H}_{4}\left(\mathrm{CH}_{2} \mathrm{SeMe}\right)_{2}\right\} \mathrm{NbCl}_{5}\right] .{ }^{12}$ There are literature data on structurally related complexes $\left[\mathrm{Nb}_{2} \mathrm{Cl}_{4}\left(\mathrm{Se}_{2}\right)_{2}(\mathrm{~L})_{4}\right]\left(\mathrm{L}=\mathrm{Me}_{2} \mathrm{~S}\right.$ or tetrahydrothiophene), made from $\mathrm{NbSeCl}_{3}$ and the appropriate ligand. ${ }^{29}$ From the viewpoint of the present work, the major points are the fragmentation of this diselenoether on reaction with $\mathrm{NbCl}_{4}$ under mild reaction conditions, and the formation of 1,3-dihydro-benzo[c]selenophane which involves $\mathrm{C}-\mathrm{Se}$ cleavage with (formally) elimination of $\mathrm{Me}_{2} \mathrm{Se}$ 
and $\mathrm{C}-\mathrm{Se}$ bond reformation and ring closure. In this case the rearrangement product appears to be the major product.

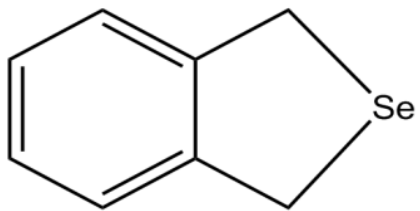

(a)

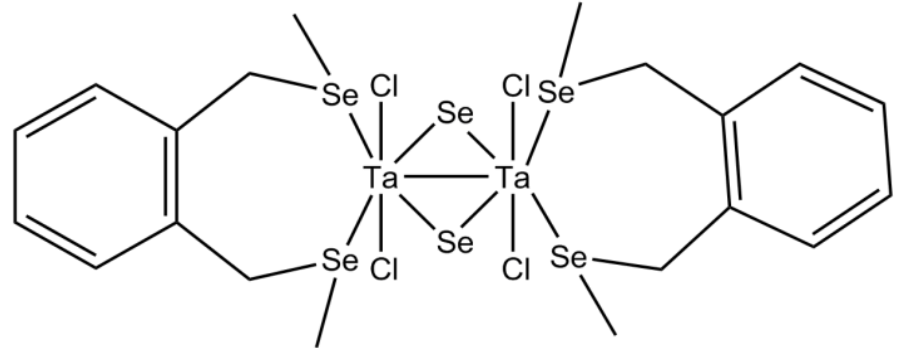

(b)

Figure 9 (a) 1,3-dihydro-benzo[c]selenophane and (b) the structure of $\left[\mathrm{Ta}_{2} \mathrm{Cl}_{4}\left\{o-\mathrm{C}_{6} \mathrm{H}_{4}\left(\mathrm{CH}_{2} \mathrm{SeMe}\right)_{2}\right\}_{2}(\mu \text {-Se })_{2}\right]$ from Reference 11.

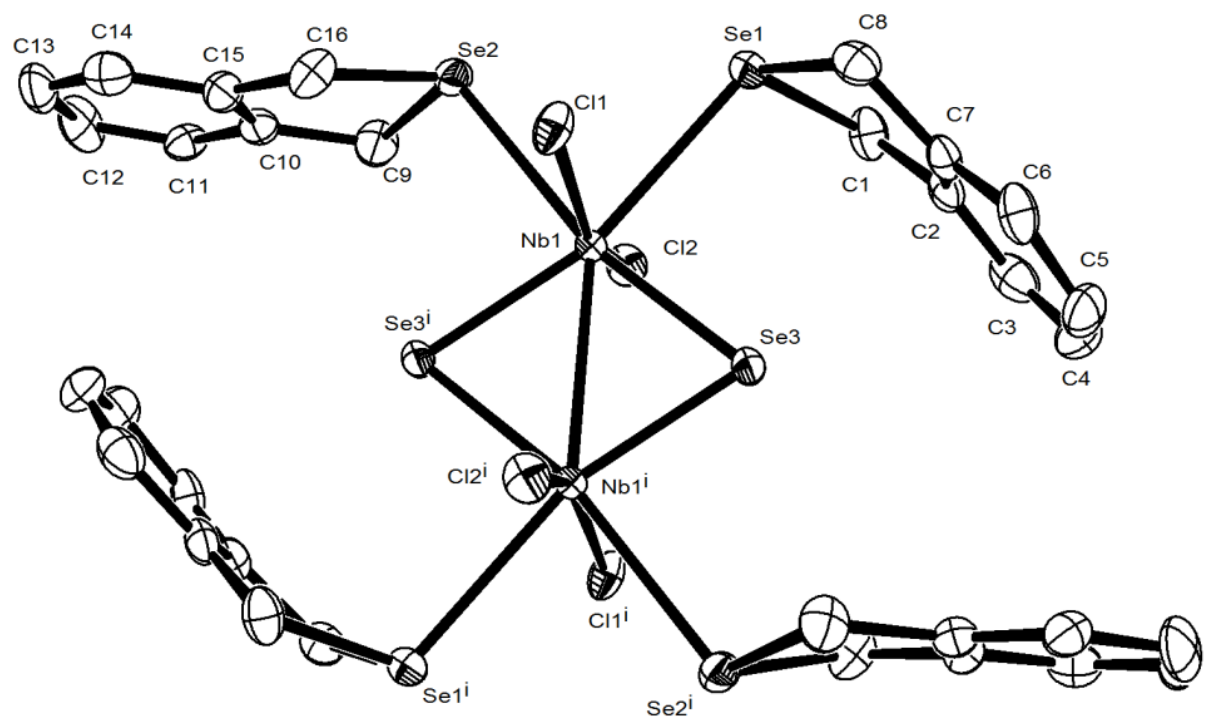

Figure 10. The structure of the major component of $\left[\mathrm{Nb}_{2} \mathrm{Cl}_{4}(\mu-\mathrm{Se})_{2}\left\{o-\mathrm{C}_{6} \mathrm{H}_{4}\left(\mathrm{CH}_{2}\right)_{2} \mathrm{Se}\right\}_{4}\right]$. Symmetry operation: $\mathrm{i}=1-\mathrm{x},-\mathrm{y},-\mathrm{z}$. See ESI for details.

Attempts to deposit niobium dichalcogenides from a range of the above complexes by low pressure CVD (LPCVD), using the equipment described elsewhere, ${ }^{10}$ were unsuccessful. The complexes $\left[\mathrm{NbCl}_{4}\left({ }^{\mathrm{n}} \mathrm{Bu}_{2} \mathrm{Se}\right)_{2}\right]$ and $\left[\mathrm{NbCl}_{4}\left\{{ }^{\mathrm{n}} \mathrm{BuSe}\left(\mathrm{CH}_{2}\right)_{3} \mathrm{Se}^{\mathrm{n}} \mathrm{Bu}\right\}\right]$ deposited metal-free, red selenium films on the cooler parts of the furnace tube, indicating the ligands were distilling off and pyrolysing, whilst thioether complexes such as $\left[\mathrm{NbCl}_{4}\left\{{ }^{\mathrm{i}} \mathrm{PrS}\left(\mathrm{CH}_{2}\right)_{2} \mathrm{~S}\right.\right.$ Pr $\left.\}\right]$, lost the chalogenoether on heating in vacuo.

\section{Conclusions}

The synthesis and characterisation of six- and eight-coordinate $\mathrm{NbCl}_{4}$ complexes with neutral sulfur and selenium ligands has been achieved. The most common type with dithio- or diseleno-ethers is the paramagnetic, six-coordinate $c i s-\left[\mathrm{NbCl}_{4}(\right.$ bidentate)], with only a single example of eight-coordination identified, in $\left[\mathrm{NbCl}_{4}\left\{\mathrm{MeS}\left(\mathrm{CH}_{2}\right)_{2} \mathrm{SMe}\right\}_{2}\right]$. The chemistry involving monodentate thio- or seleno-ethers is 
more complicated, and it seems that in most of the systems studied, both 1:1 and 2:1 ligand:metal complexes form, and probably both are present in solutions made from the isolated complexes. The 1:1 species are diamagnetic dimers, $\left[\left(\mathrm{Me}_{2} \mathrm{E}\right) \mathrm{Cl}_{3} \mathrm{Nb}(\mu-\mathrm{Cl})_{2} \mathrm{NbCl}_{3}\left(\mathrm{Me}_{2} \mathrm{E}\right)\right]$, in the solid state, whilst the 2:1 complexes appear to be six-coordinate monomers for $\left[\mathrm{NbCl}_{4}\left(\mathrm{Me}_{2} \mathrm{~S}\right)_{2}\right]$ and $\left[\mathrm{NbCl}_{4}\left({ }^{\mathrm{n}} \mathrm{Bu}_{2} \mathrm{Se}\right)_{2}\right]$, although solution instability has prevented X-ray crystallographic confirmation. The unpredictability in these systems is illustrated by the structure of the 2:1 dimethyltelluride complex which is an eight-coordinate dimer, $\left.\left[\mathrm{Nb}_{2} \mathrm{Cl}_{4}(\mu-\mathrm{Cl})_{4} \mathrm{Me}_{2} \mathrm{Te}\right)_{4}\right]$; it is possible that $\left[\mathrm{NbCl}_{4}\left(\mathrm{Me}_{2} \mathrm{Se}\right)_{2}\right]$ is also dimeric based upon spectroscopic data. Comparison with the corresponding phosphine systems, ${ }^{14,18,23}$ shows considerable similarities, not least in that solid state and solution speciation, even in non-coordinating solvents, often appear to be different. Generally the phosphine ligands seem to more readily achieve eight-coordination than the chalcogenoether systems, probably due to their stronger donor properties, combined with weaker metal-ligand bonds in the higher coordination number species. As observed in the phosphine systems, ${ }^{18}$ hydrolysis/oxidation of $\mathrm{Nb}(\mathrm{IV})$ to $\mathrm{Nb}(\mathrm{V})$ occurs readily. Further complexity in the chalcogenoether systems arises from $\mathrm{C}-\mathrm{E}$ bond cleavage under some conditions, which can result in incorporation of ligand decomposition products into the niobium complexes. Despite this ready $\mathrm{C}-\mathrm{E}$ bond fission, these complexes turn out to be unsuitable as single source LPCVD reagents, probably due to insufficient volatility or ready loss of the chalcogenoether ligands at elevated temperature.

\section{Acknowledgements}

We thank the University of Southampton for support via a VC scholarship to Y.-P. C. We also thank Dr W. Zhang for assistance with the X-ray data analysis.

\section{Supplementary Data}

Crystallographic data in cif format have been deposited with the Cambridge Crystallographic Data Centre (CCDC) and given numbers 1494381-1494392.

CCDC $1494381 \mathrm{C}_{32} \mathrm{H}_{32} \mathrm{Cl}_{4} \mathrm{Nb}_{2} \mathrm{Se}_{6}$ : CCDC $1494382 \mathrm{C}_{4} \mathrm{H}_{12} \mathrm{ClNb}_{2} \mathrm{~S}_{2}$ : CCDC $1494383 \mathrm{C}_{4} \mathrm{H}_{12} \mathrm{Cl}_{8} \mathrm{Nb}_{2} \mathrm{Se}_{2}$ : CCDC $1494384 \mathrm{C}_{8} \mathrm{H}_{24} \mathrm{Cl}_{8} \mathrm{Nb}_{2} \mathrm{Te}_{4}$ : CCDC $1494385 \mathrm{C}_{8} \mathrm{H}_{20} \mathrm{Cl}_{4} \mathrm{NbS}_{4}$ : CCDC $1494386 \mathrm{C}_{8} \mathrm{H}_{18} \mathrm{Cl}_{4} \mathrm{NbS}_{2}$ : CCDC $1494387 \mathrm{C}_{5} \mathrm{H}_{12} \mathrm{Cl}_{4} \mathrm{NbS}_{2}$ : CCDC $1494388 \mathrm{C}_{4} \mathrm{H}_{10} \mathrm{Cl}_{4} \mathrm{NbS}_{2}$ : CCDC $1494389 \mathrm{C}_{5} \mathrm{H}_{12} \mathrm{Cl}_{4} \mathrm{NbSe}_{2}$ : CCDC 1494390 $\mathrm{C}_{12} \mathrm{H}_{18} \mathrm{Cl}_{4} \mathrm{NbS}_{2}$ :CCDC $1494391 \mathrm{C}_{2} \mathrm{H}_{6} \mathrm{Cl}_{3} \mathrm{NbOS}$ : CCDC $1494392 \mathrm{C}_{4} \mathrm{H}_{10} \mathrm{Cl}_{3} \mathrm{NbOS}_{2}$. Copies of the data can be obtained free of charge from The Director, CCDC, 12 Union Road, Cambridge, CB2 1EZ, UK, fax: +44 1223 366033, e-mail: deposit@ccdc.cam.ac.uk or on the web at http://www.ccdc.cam.ac.uk.

ESI for this paper contains X-ray crystallographic data for the $\mathrm{Nb}(\mathrm{V})$ byproducts $\left[\mathrm{NbOCl}_{3}\left(\mathrm{Me}_{2} \mathrm{~S}\right)\right]$ and $\left[\mathrm{NbOCl}_{3}\left\{\mathrm{MeS}\left(\mathrm{CH}_{2}\right)_{2} \mathrm{SMe}\right\}\right]$ and some further discussion on the disorder problem in $\left[\mathrm{Nb}_{2} \mathrm{Cl}_{4}(\mu-\mathrm{Se})_{2}\{o-\right.$ $\left.\left.\mathrm{C}_{6} \mathrm{H}_{4}\left(\mathrm{CH}_{2}\right)_{2} \mathrm{Se}\right\}_{4}\right]$.

\section{References}

1. W. Levason and G. Reid, J. Chem. Res. (S), 2002, 467.

2. W. Levason, S. D. Orchard and G. Reid, Coord. Chem. Rev., 2002, 225, 159.

3. T. J. Meyer and J. A. McCleverty (Eds) Comprehensive Coordination Chemistry II, vols 4, 5, Elsevier, Oxford (2004). 
4. M. Chhowalla, H. S. Shin, G. Eda, L.-J. Li, K. P. Loh and H. Zhang, Nat. Chem., 2013, 5, 263; J. Liu and X.-W. Liu, Adv. Mater., 2012, 24, 4097.

5. Q. Xiang, J. Yu and M. Jaroniec, J. Am. Chem. Soc., 2012, 134, 6575; J. Pu, Y. Yomogida, K.-K. Liu, L.-J. Li, Y. Iwasa and T. Takenobu, Nano Lett., 2012, 12, 4013; K. Lee, R. Gatensby, N. McEvoy, T. Hallam and G. S. Duesberg, Adv. Mater., 2013, 25, 6699; Y. Ma, Y. Dsi, M. Guo, C. Niu, Y. Zhu and B. Huang, ACS Nano, 2012, 6, 1695; K. Xu, P. Chen, X. Li, C. Wu, Y. Guo, J. Zhao, X. Wu and Y. Xie, Angew. Chem., Int. Ed. 2013, 5210477.

6. A. C. Jones and M. L. Hitchman, in Chemical Vapour Deposition: Precursors, Processes and Applications, Royal Society of Chemistry (2009).

7. N. D. Boscher, C. J. Carmalt, and I. P. Parkin, Eur. J. Inorg. Chem., 2006, 1255; E. Peters, C. J. Carmalt, I. P. Parkin and D. A. Tocher, Eur. J. Inorg. Chem., 2005, 4179; C. J. Carmalt, E. S. Peters, I. P. Parkin, T. D. Manning and A. L. Hector, Eur. J. Inorg. Chem., 2004, 4470.

8. P. J. McKarns, T. S. Lewkebandara, G. P. A. Yap, L. M. Liable-Sands, A. L. Rheingold and C. H. Winter, Inorg. Chem., 1998, 37, 418; P. J. McKarns, M. J. Heeg and C. H. Winter, Inorg. Chem., 1998, 37, 4743.

9. A. L. Hector, M. Jura, W. Levason, S. D. Reid and G. Reid, New J. Chem., 2009, 33, 641; A. L. Hector, W. Levason, G. Reid, S. D. Reid and M. Webster, Chem. Mater., 2008, 20, 5100; S. D. Reid, A. L. Hector, W. Levason, G. Reid, B. J. Waller and M. Webster, Dalton Trans., 2007, 4769.

10. S. L. Benjamin, Y-P. Chang, C. Gurnani, A. L. Hector, M. Huggon, W. Levason and G. Reid, Dalton Trans., 2014, 43, 16640.

11. S. L. Benjamin, Y-P. Chang, M. Huggon, W. Levason and G. Reid, Polyhedron, 2015, 99, 230.

12. M. Jura, W. Levason, R. Ratnani, G. Reid and M. Webster. Dalton Trans., 2010, 39, 883.

13. F. Fairbrother, K. H. Grundy and A. Thompson, J. Chem. Soc., 1965, 765; F. Fairbrother and J. F. Nixon, J. Chem. Soc., 1962, 150; A. Merbach and J. C. Bunzli, Helv. Chim. Acta, 1972, 55, 580.

14. J. A. Canich and F. A. Cotton, Inorg. Chem., 1987, 26, 3473; E. Babaian-Kibala, F. A. Cotton and P. A. Kibala, Inorg. Chem., 1990, 29, 4002, and refs therein.

15. J. B. Hamilton and R. E. McCarley, Inorg. Chem., 1970, 9, 1333.

16. G. W. A. Fowles, D. J. Tidmarsh and R. A. Walton, J. Inorg. Nucl. Chem., 1969, 31, 2373.

17. J. B. Hamilton and R. E. McCarley, Inorg. Chem., 1970, 9, 1339.

18. S. L. Benjamin, Y.-P. Chang, A. L. Hector, M. Jura, W. Levason, G. Reid, and G. Stenning, Dalton Trans., 2016, 45, 8192.

19. F. R. Hartley, S. G. Murray, W. Levason, H. E. Soutter and C. A. McAuliffe, Inorg. Chim. Acta, 1979, 35, 265; D. J. Gulliver, E. G. Hope, W. Levason, S. G. Murray, D. M. Potter and G. L. Marshall, J. Chem. Soc., Perkin Trans. II, 1984, 429; W. Levason, M. Nirwan, R. Ratnani, G. Reid, N. Tsoureas and M. Webster, Dalton Trans., 2007, 439.

20. E. G. Hope, T. Kemmitt, and W. Levason, Organometallics, 1988, 7, 78; T. Kemmitt and W. Levason, Organometallics, 1989, 8, 1303; K. George, C. H. de Groot, C. Gurnani, A. L. Hector, R. Huang, M. Jura, W. Levason and G. Reid, Chem. Mater., 2013, 25, 1829. 
21. G. M. Sheldrick, Acta Crystystallog. Sect. C, 2015, 71, 3.

22. X CrystalClear-SM Expert 3.1 b27, Rigaku Corporation, Tokyo, Japan, 2012; CrystalClear-SM Expert 2.1 b29, Rigaku Corporation, Tokyo, Japan, 2013; CrysAlis PRO. Agilent Technologies Ltd., Yarnton, Oxfordshire, England.

23. F. A. Cotton, S. A. Duraj and W. J. Roth, Inorg. Chem., 1984, 23, 3592; F. A. Cotton, M. P. Diebold and W. J. Roth, Polyhedron, 1985, 4, 1103; F. A. Cotton, M. P. Diebold and W. J. Roth, Inorg. Chim. Acta, 1985, 105, 41; F. A. Cotton and W. J. Roth, Inorg. Chem., 1984, 23, 945; P. D. W. Boyd, A. J. Nielson and C. E. F. Rickard, J. Chem. Soc., Dalton Trans., 1987, 307.

24. J. K. Burdett, R. Hoffmann and R. C. Fay, Inorg. Chem., 1978, 17, 2553; F. A. Cotton, L. R. Falvello and R. C. Najjar, Inorg. Chem., 1983, 22, 770.

24. R. Hart, W. Levason, B. Patel and G. Reid, J. Chem. Soc., Dalton Trans., 2002, 3153.

25. M. Valloton and A. E. Merbach, Helv. Chim. Acta, 1975, 58, 2272.

26. B. E. Norcross, J. M. Lansinger and R. L.Martin, J. Org. Chem., 1977, 42, 369.

27. C. Gurnani, W. Levason, R. Ratnani, G. Reid and M. Webster, Dalton Trans., 2008, 6274; C. Gurnani, M. Jura, W. Levason, R. Ratnani, G. Reid and M. Webster, Dalton Trans., 2009, 1611.

28. S. D. Reid, A. L. Hector, W. Levason, G. Reid, B. J. Waller and M. Webster, Dalton Trans., 2007, 4769 .

29. M. G. B. Drew, D. A. Rice and D. M. Williams, Acta Crystallogr. Sect. C: Cryst. Struct. Commun., 1984, 40, 1547; M. G. B. Drew, D. A. Rice and D. M. Williams, J. Chem. Soc., Dalton Trans., 1984, 1087. 
Table $1 \mathrm{X}$-ray crystallographic data ${ }^{\mathrm{a}, \mathrm{b}}$

\begin{tabular}{|c|c|c|}
\hline Compound & {$\left[\mathrm{NbCl}_{4}\left\{\mathrm{MeS}\left(\mathrm{CH}_{2}\right)_{2} \mathrm{SMe}\right\}_{2}\right]$} & {$\left[\mathrm{NbCl}_{4}\left\{\mathrm{MeS}\left(\mathrm{CH}_{2}\right)_{2} \mathrm{SMe}\right\}\right]$} \\
\hline Formula & $\mathrm{C}_{8} \mathrm{H}_{20} \mathrm{Cl}_{4} \mathrm{NbS}_{4}$ & $\mathrm{C}_{4} \mathrm{H}_{10} \mathrm{Cl}_{4} \mathrm{NbS}_{2}$ \\
\hline Formula weight & 479.19 & 365.95 \\
\hline Crystal system & Tetragonal & Monoclinic \\
\hline Space group (no.) & $\mathrm{P}_{3}{ }_{2} 22(96)$ & $\mathrm{P} 2{ }_{1}(4)$ \\
\hline a/ $\AA$ & $9.141(1)$ & $7.2443(3)$ \\
\hline $\mathrm{b} / \AA$ & $9.141(1)$ & $11.2723(4)$ \\
\hline c/ $\AA$ & $20.574(2)$ & $7.9616(3)$ \\
\hline$\alpha / \operatorname{deg}$ & 90 & 90 \\
\hline$\beta / \operatorname{deg}$ & 90 & $116.177(5)$ \\
\hline$\gamma / \operatorname{deg}$ & 90 & 90 \\
\hline $\mathrm{U} / \AA^{3}$ & 1719.1(2) & $583.46(4)$ \\
\hline $\mathrm{Z}$ & 4 & 2 \\
\hline$\mu(\mathrm{Mo}-\mathrm{K} \alpha) / \mathrm{mm}^{-1}$ & 1.786 & 2.248 \\
\hline $\mathrm{F}(000)$ & 964 & 350 \\
\hline Total no. reflections & 7720 & 3485 \\
\hline Unique reflections & 1691 & 2002 \\
\hline $\mathrm{R}_{\text {int }}$ & 0.062 & 0.014 \\
\hline $\begin{array}{l}\text { No. of parameters, } \\
\text { restraints }\end{array}$ & 80,0 & 102,1 \\
\hline $\mathrm{R}_{1}^{\mathrm{b}}\left[\mathrm{I}_{\mathrm{o}}>2 \sigma\left(\mathrm{I}_{\mathrm{o}}\right)\right]$ & 0.027 & 0.018 \\
\hline $\mathrm{R}_{1}$ (all data) & 0.033 & 0.018 \\
\hline $\mathrm{wR}_{2}{ }^{\mathrm{b}}\left[\mathrm{I}_{\mathrm{o}}>2 \sigma\left(\mathrm{I}_{\mathrm{o}}\right)\right]$ & 0.058 & 0.045 \\
\hline$w_{2}$ (all data) & 0.059 & 0.045 \\
\hline
\end{tabular}


Table 1 cont.

\begin{tabular}{|c|c|c|}
\hline Compound & {$\left[\mathrm{NbCl}_{4}\left\{{ }^{\mathrm{i}} \operatorname{PrS}\left(\mathrm{CH}_{2}\right)_{2} \mathrm{~S} \operatorname{Pr}\right\}\right]$} & {$\left[\mathrm{NbCl}_{4}\left\{\mathrm{MeS}\left(\mathrm{CH}_{2}\right)_{3} \mathrm{SMe}\right\}\right]$} \\
\hline Formula & $\mathrm{C}_{8} \mathrm{H}_{18} \mathrm{Cl}_{4} \mathrm{NbS}_{2}$ & $\mathrm{C}_{5} \mathrm{H}_{12} \mathrm{Cl}_{4} \mathrm{NbS}_{2}$ \\
\hline Formula weight & 413.05 & 370.98 \\
\hline Crystal system & Monoclinic & Tetragonal \\
\hline Space group (no.) & $\mathrm{P} 2_{1} / \mathrm{c}(14)$ & $\mathrm{I}-42 \mathrm{~d}(122)$ \\
\hline a/ $\AA$ & $8.7424(4)$ & $9.964(3)$ \\
\hline $\mathrm{b} / \AA$ & $9.2175(3)$ & $9.964(3)$ \\
\hline c/ $\AA$ & $19.6381(9)$ & 25.11(1) \\
\hline$\alpha / \operatorname{deg}$ & 90 & 90 \\
\hline$\beta / \operatorname{deg}$ & $98.649(4)$ & 90 \\
\hline$\gamma / \operatorname{deg}$ & 90 & 90 \\
\hline $\mathrm{U} / \AA^{3}$ & $1564.5(1)$ & $2493(2)$ \\
\hline $\mathrm{Z}$ & 4 & 8 \\
\hline$\mu(\mathrm{Mo}-\mathrm{K} \alpha) / \mathrm{mm}^{-1}$ & 1.690 & 2.108 \\
\hline $\mathrm{F}(000)$ & 828 & 1464 \\
\hline Total no. reflections & 10862 & 3934 \\
\hline Unique reflections & 4029 & 1225 \\
\hline $\mathrm{R}_{\text {int }}$ & 0.053 & 0.074 \\
\hline $\begin{array}{l}\text { No. of parameters, } \\
\text { restraints }\end{array}$ & 140,0 & 58,0 \\
\hline $\mathrm{R}_{1}^{\mathrm{b}}\left[\mathrm{I}_{\mathrm{o}}>2 \sigma\left(\mathrm{I}_{\mathrm{o}}\right)\right]$ & 0.061 & 0.052 \\
\hline $\mathrm{R}_{1}$ (all data) & 0.105 & 0.082 \\
\hline $\mathrm{wR}_{2}^{\mathrm{b}}\left[\mathrm{I}_{\mathrm{o}}>2 \sigma\left(\mathrm{I}_{\mathrm{o}}\right)\right]$ & 0.122 & 0.121 \\
\hline $\mathrm{wR}_{2}$ (all data) & 0.140 & 0.134 \\
\hline
\end{tabular}


Table 1 cont.

\begin{tabular}{|c|c|c|}
\hline Compound & {$\left[\mathrm{NbCl}_{4}\left\{\mathrm{MeSe}\left(\mathrm{CH}_{2}\right)_{3} \mathrm{SeMe}\right\}\right]$} & {$\left[\mathrm{NbCl}_{4}\left(\mathrm{o}-\mathrm{C}_{6} \mathrm{H}_{4}\left(\mathrm{CH}_{2} \mathrm{SEt}\right)_{2}\right]\right.$} \\
\hline Formula & $\mathrm{C}_{5} \mathrm{H}_{12} \mathrm{Cl}_{4} \mathrm{NbSe}_{2}$ & $\mathrm{C}_{12} \mathrm{H}_{18} \mathrm{Cl}_{4} \mathrm{NbS}_{2}$ \\
\hline Formula weight & 464.78 & 461.09 \\
\hline Crystal system & Tetragonal & Orthorhombic \\
\hline Space group (no) & $\mathrm{I} 4_{1} / \mathrm{a}(88)$ & Pnma (62) \\
\hline $\mathrm{a} / \AA$ & $9.9381(2)$ & $19.407(9)$ \\
\hline $\mathrm{b} / \AA$ & $9.9381(2)$ & $12.502(6)$ \\
\hline c/ $\AA$ & $26.265(1)$ & $7.084(3)$ \\
\hline$\alpha / \operatorname{deg}$ & 90 & 90 \\
\hline$\beta / \operatorname{deg}$ & 90 & 90 \\
\hline$\gamma / \operatorname{deg}$ & 90 & 90 \\
\hline $\mathrm{U} / \AA^{3}$ & $2594.1(2)$ & $1718(1)$ \\
\hline $\mathrm{Z}$ & 8 & 4 \\
\hline$\mu(\mathrm{Mo}-\mathrm{K} \alpha) / \mathrm{mm}^{-1}$ & 7.317 & 1.549 \\
\hline $\mathrm{F}(000)$ & 1752 & 924 \\
\hline Total no. reflections & 8738 & 8916 \\
\hline Unique reflections & 1281 & 1768 \\
\hline $\mathrm{R}_{\text {int }}$ & 0.083 & 0.075 \\
\hline $\begin{array}{l}\text { No. of parameters, } \\
\text { restraints }\end{array}$ & 58,0 & 92,0 \\
\hline $\mathrm{R}_{1}{ }^{\mathrm{b}}\left[\mathrm{I}_{\mathrm{o}}>2 \sigma\left(\mathrm{I}_{\mathrm{o}}\right)\right]$ & 0.028 & 0.033 \\
\hline $\mathrm{R}_{1}$ (all data) & 0.030 & 0.049 \\
\hline $\mathrm{wR}_{2}^{\mathrm{b}}\left[\mathrm{I}_{\mathrm{o}}>2 \sigma\left(\mathrm{I}_{\mathrm{o}}\right)\right]$ & 0.069 & 0.068 \\
\hline $\mathrm{wR}_{2}$ (all data) & 0.070 & 0.074 \\
\hline
\end{tabular}


Table 1 cont.

\begin{tabular}{|c|c|c|}
\hline Compound & {$\left[\mathrm{Nb}_{2} \mathrm{Cl}_{8}\left(\mathrm{Me}_{2} \mathrm{~S}\right)_{2}\right]$} & {$\left[\mathrm{Nb}_{2} \mathrm{Cl}_{8}\left(\mathrm{Me}_{2} \mathrm{Se}\right)_{2}\right]$} \\
\hline Formula & $\mathrm{C}_{4} \mathrm{H}_{12} \mathrm{Cl}_{8} \mathrm{Nb}_{2} \mathrm{~S}_{2}$ & $\mathrm{C}_{4} \mathrm{H}_{12} \mathrm{Cl}_{8} \mathrm{Nb}_{2} \mathrm{Se}_{2}$ \\
\hline Formula weight & 593.68 & 687.48 \\
\hline Crystal system & Monoclinic & Orthorhombic \\
\hline Space group (no) & $\mathrm{P} 2_{1} / \mathrm{n}(14)$ & Cmca (64) \\
\hline $\mathrm{a} / \AA$ & $6.4589(2)$ & $10.4725(8)$ \\
\hline $\mathrm{b} / \AA$ & $10.1598(4)$ & $7.2592(5)$ \\
\hline c/ $\AA$ & $13.1644(5)$ & $22.501(1)$ \\
\hline$\alpha / \operatorname{deg}$ & 90 & 90 \\
\hline$\beta / \operatorname{deg}$ & $94.499(4)$ & 90 \\
\hline$\gamma / \operatorname{deg}$ & 90 & 90 \\
\hline $\mathrm{U} / \AA^{3}$ & $861.20(5)$ & $1710.6(2)$ \\
\hline Z & 2 & 4 \\
\hline$\mu(\mathrm{Mo}-\mathrm{K} \alpha) / \mathrm{mm}^{-1}$ & 2.787 & 6.818 \\
\hline $\mathrm{F}(000)$ & 572 & 1288 \\
\hline Total no. reflections & 5264 & 5388 \\
\hline Unique reflections & 1690 & 888 \\
\hline $\mathrm{R}_{\text {int }}$ & 0.020 & 0.066 \\
\hline $\begin{array}{l}\text { No. of parameters, } \\
\text { restraints }\end{array}$ & 75,0 & 44,0 \\
\hline $\mathrm{R}_{1}^{\mathrm{b}}[\mathrm{Io}>2 \sigma(\mathrm{Io})]$ & 0.021 & 0.029 \\
\hline $\mathrm{R}_{1}$ (all data) & 0.023 & 0.039 \\
\hline $\mathrm{wR}_{2}{ }^{\mathrm{b}}[\mathrm{Io}>2 \sigma(\mathrm{Io})]$ & 0.051 & 0.060 \\
\hline$w_{2}$ (all data) & 0.052 & 0.064 \\
\hline
\end{tabular}


Table 1 cont.

\begin{tabular}{|c|c|c|}
\hline Compound & {$\left[\mathrm{Nb}_{2} \mathrm{Cl}_{8}\left(\mathrm{Me}_{2} \mathrm{Te}\right)_{4}\right]$} & {$\left[\mathrm{Nb}_{2} \mathrm{Cl}_{4}(\mu-\mathrm{Se})_{2}\left\{o-\mathrm{C}_{6} \mathrm{H}_{4}\left(\mathrm{CH}_{2}\right)_{2} \mathrm{Se}\right\}_{4}\right]$} \\
\hline Formula & $\mathrm{C}_{8} \mathrm{H}_{24} \mathrm{Cl}_{8} \mathrm{Nb}_{2} \mathrm{Te}_{4}$ & $\mathrm{C}_{32} \mathrm{H}_{32} \mathrm{Cl}_{4} \mathrm{Nb}_{2} \mathrm{Se}_{6}$ \\
\hline Formula weight & 1100.09 & 1217.95 \\
\hline Crystal system & Tetragonal & Monoclinic \\
\hline Space group (no) & $\mathrm{P} 4{ }_{2} 2_{1} 2(94)$ & $\mathrm{P} 2{ }_{1} / \mathrm{c}(14)$ \\
\hline a/ $\AA$ & $10.4835(1)$ & $10.6850(5)$ \\
\hline b/ $\AA$ & $10.4835(1)$ & $12.3759(5)$ \\
\hline c/ $\AA$ & $12.0612(2)$ & $14.1909(7)$ \\
\hline$\alpha / \operatorname{deg}$ & 90 & 90 \\
\hline$\beta / \operatorname{deg}$ & 90 & $106.821(5)$ \\
\hline$\gamma / \operatorname{deg}$ & 90 & 90 \\
\hline $\mathrm{U} / \AA^{3}$ & $1325.57(3)$ & $1796.2(2)$ \\
\hline $\mathrm{Z}$ & 2 & 2 \\
\hline$\mu(\mathrm{Mo}-\mathrm{K} \alpha) / \mathrm{mm}^{-1}$ & 5.979 & 7.039 \\
\hline $\mathrm{F}(000)$ & 996 & 1156 \\
\hline Total no. reflections & 8870 & 18891 \\
\hline Unique reflections & 1315 & 3436 \\
\hline $\mathrm{R}_{\text {int }}$ & 0.030 & 0.0761 \\
\hline $\begin{array}{l}\text { No. of parameters, } \\
\text { restraints }\end{array}$ & 54,0 & 205,0 \\
\hline $\mathrm{R}_{1}^{\mathrm{b}}\left[\mathrm{I}_{\mathrm{o}}>2 \sigma\left(\mathrm{I}_{\mathrm{o}}\right)\right]$ & 0.012 & 0.0498 \\
\hline $\mathrm{R}_{1}$ (all data) & 0.012 & 0.0854 \\
\hline $\mathrm{wR}_{2}^{\mathrm{b}}\left[\mathrm{I}_{\mathrm{o}}>2 \sigma\left(\mathrm{I}_{\mathrm{o}}\right)\right]$ & 0.030 & 0.0939 \\
\hline$w_{2}$ (all data) & 0.030 & 0.1052 \\
\hline
\end{tabular}


Table 1 cont.

Compound

Formula

Formula weight

Crystal system

Space group (no)

a/ $\AA$

b/ $\AA$

c/ $\AA$

$\alpha / \operatorname{deg}$

$\beta / \operatorname{deg}$

$\gamma / \operatorname{deg}$

$\mathrm{U} / \AA^{3}$

$\mathrm{Z}$

$\mu(\mathrm{Mo}-\mathrm{K} \alpha) / \mathrm{mm}^{-1}$

$\mathrm{F}(000)$

Total no. reflections

Unique reflections

$\mathrm{R}_{\text {int }}$

No. of parameters, restraints

$\mathrm{R}_{1}^{\mathrm{b}}\left[\mathrm{I}_{\mathrm{o}}>2 \sigma\left(\mathrm{I}_{\mathrm{o}}\right)\right]$

$\mathrm{R}_{1}$ (all data)

$w_{2}{ }^{b}\left[I_{0}>2 \sigma\left(I_{0}\right)\right]$

$\mathrm{wR}_{2}$ (all data)
$\left[\mathrm{Nb}_{2} \mathrm{Cl}_{4} \mathrm{~S}_{2}\left\{\mathrm{MeS}\left(\mathrm{CH}_{2}\right)_{2} \mathrm{SMe}\right\}_{2}\right]$

\section{$\mathrm{C}_{10} \mathrm{H}_{24} \mathrm{Cl}_{4} \mathrm{Nb}_{2} \mathrm{~S}_{6}$}

664.27

Orthorhombic

Pnnm (58)

10.8359(6)

10.0475(7)

10.1149(6)

90

90

90

1101.3(1)

2

2.087

660

8409

1149

0.092

58,0

0.033

0.043

0.081

0.085 


\section{ESI}

\section{Niobium tetrachloride complexes with thio-, seleno- and telluro-ether coordination - synthesis and structures}

Yao-Pang Chang, William Levason, Mark E. Light and Gillian Reid

As noted in the main text, trace hydrolysis/air oxidation in the $\mathrm{Nb}(\mathrm{IV})$ systems can lead to $\mathrm{Nb}(\mathrm{V})$ products. Crystals of two examples containing $\mathrm{NbOCl}_{3}$ were isolated in this work and their structures determined.

\section{$\left[\mathrm{NbOCl}_{3}\left(\mathrm{Me}_{2} \mathrm{~S}\right)\right]$}

The green crystals were formed during recrystallisation of brown $\left[\mathrm{NbCl}_{4}\left(\mathrm{Me}_{2} \mathrm{~S}\right)_{2}\right]$ from $\mathrm{CH}_{2} \mathrm{Cl}_{2}$ by layered with n-hexane. The structure contains two slightly different molecules in the unit cell, both square pyramidal with an apical oxo-group which are linked into chains by asymmetric oxido-bridges, $\mathrm{Nb1}-\mathrm{O} 1=1.744(3)$, $\mathrm{Nb} 1-\mathrm{O} 1^{\mathrm{ii}}=2.224(3)$. (Figure $\mathrm{S} 1$ ). As observed for the $\mathrm{Nb}(\mathrm{IV})$ complexes, there is little difference in $\mathrm{Nb}-\mathrm{Cl}_{\text {trans }}$ and $\mathrm{Nb}-\mathrm{Cl}_{\text {transCl. }}$.
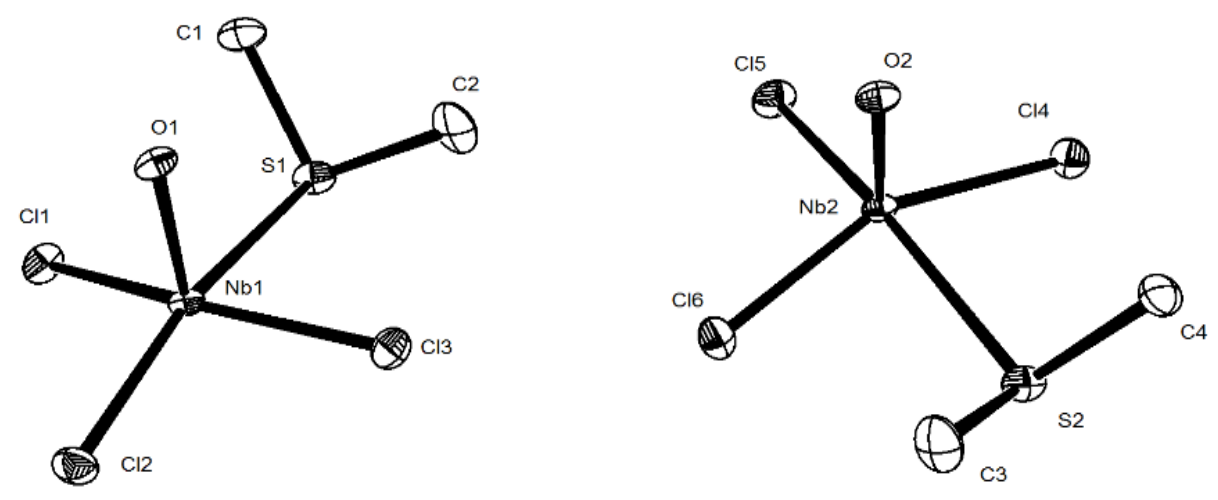

(a) 


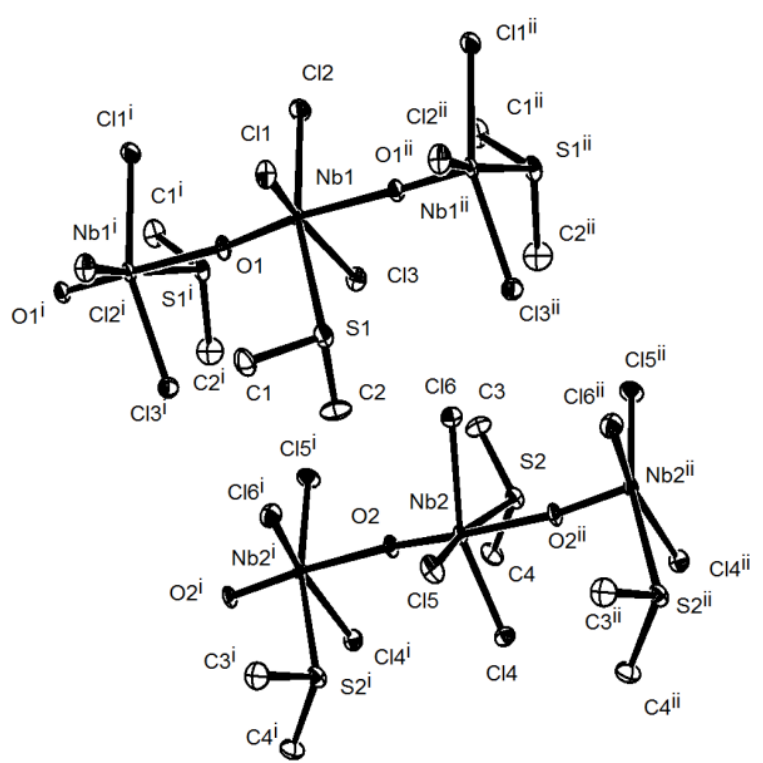

(b)

Figure $\mathrm{S} 1$ (a) The structure of $\left.\left[\mathrm{NbOCl}_{3}\left(\mathrm{Me}_{2} \mathrm{~S}\right)\right]\right]$ showing the atom numbering scheme and with ellipsoids drawn at the 50\% probability level. Hydrogen atoms are omitted for clarity. Selected bond lengths (A) and angles $\left({ }^{\circ}\right)$ : $\mathrm{Nb} 1-\mathrm{O} 1=1.744(3), \mathrm{Nb} 1-\mathrm{O} 1^{\mathrm{ii}}=2.224(3), \mathrm{Nb} 1-\mathrm{Cl} 1=2.336(1), \mathrm{Nb} 1-\mathrm{Cl} 2=2.310(1), \mathrm{Nb} 1-\mathrm{Cl} 3=$ 2.360(2), $\mathrm{Nb} 1-\mathrm{S} 1=2.692(2), \mathrm{Nb} 2-\mathrm{O} 2=1.746(3), \mathrm{Nb} 2-\mathrm{O} 2^{\mathrm{ii}}=2.232(3), \mathrm{Nb} 2-\mathrm{Cl} 4=2.332(2), \mathrm{Nb} 2-\mathrm{Cl} 5=$ $2.336(1), \mathrm{Nb} 2-\mathrm{Cl} 6=2.344(2), \mathrm{Nb} 2-\mathrm{S} 2=2.684(1) ; \mathrm{O} 1-\mathrm{Nb} 1-\mathrm{O} 1^{\mathrm{ii}}=172.5(2), \mathrm{O} 1-\mathrm{Nb} 1-\mathrm{Cl} 1=97.6(1)$, $\mathrm{O} 1-\mathrm{Nb} 1-\mathrm{Cl} 2=100.3(1), \mathrm{O} 1-\mathrm{Nb} 1-\mathrm{Cl} 3=96.3(1), \mathrm{O} 1-\mathrm{Nb} 1-\mathrm{S} 1=93.9(1), \mathrm{Nb} 1-\mathrm{O} 1-\mathrm{Nb} 1^{\mathrm{i}}=171.9(2)$, $\mathrm{O} 2-\mathrm{Nb} 2-\mathrm{O} 2^{\mathrm{ii}}=173.16(7), \mathrm{O} 2-\mathrm{Nb} 2-\mathrm{Cl} 4=97.5(1), \mathrm{O} 2-\mathrm{Nb} 2-\mathrm{Cl} 5=99.7(1), \mathrm{O} 2-\mathrm{Nb} 2-\mathrm{Cl} 6=97.0(1)$, $\mathrm{O} 2-\mathrm{Nb} 2-\mathrm{S} 2=93.3(1), \mathrm{Nb} 2-\mathrm{O} 2-\mathrm{Nb} 2^{\mathrm{i}}=168.9(2)$. Symmetry operation: $\mathrm{i}=\mathrm{x},-\mathrm{y}+1 / 2, \mathrm{z}+1 / 2, \mathrm{ii}=\mathrm{x},-\mathrm{y}+1 / 2$, $\mathrm{z}-1 / 2$, (b) the polymeric chain.

$\mathrm{The} \mathrm{Nb}-\mathrm{Cl}$ and $\mathrm{Nb}-\mathrm{S}$ distances seem unexceptional, and the disparate $\mathrm{Nb}-\mathrm{O}$ are similar to those found in solid $\mathrm{NbOCl}_{3}$, ${ }^{\mathrm{S} 1}$ which is dimeric with each niobium in an edge-linked distorted octahedron of four chlorines and two trans oxides $(\mathrm{Nb}-\mathrm{O}=2.203(3), 1.758(3) \AA)$, which weakly link the dimers into polymer chains.

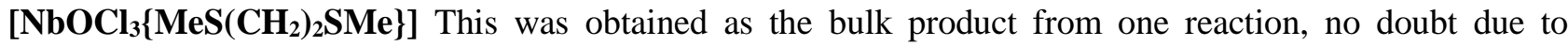
adventitious oxidation/hydrolysis.

$\mathrm{NbCl}_{4}(73 \mathrm{mg}, 0.3 \mathrm{mmol})$ was suspended in $\mathrm{CH}_{2} \mathrm{Cl}_{2}(15 \mathrm{~mL})$ at room temperature. A solution of $\mathrm{MeS}\left(\mathrm{CH}_{2}\right)_{2} \mathrm{SMe}(36.6 \mathrm{mg}, 0.3 \mathrm{mmol})$ and $\mathrm{CH}_{2} \mathrm{Cl}_{2}(2 \mathrm{~mL})$ was added and the mixture stirred overnight. After filtering the pale green solution was evaporated in vacuo, leaving a pale green powder. Yield: $39 \mathrm{mg}, 36 \%$. Required for $\mathrm{C}_{4} \mathrm{H}_{10} \mathrm{Cl}_{3} \mathrm{NbOS}_{2}$ (337.52): C, 14.23; H, 2.99. Found: C, 13.55; H 2.94. IR (Nujol, $\mathrm{cm}^{-1}$ ): 939 $(\mathrm{Nb}=\mathrm{O}), 325,344,363(\mathrm{Nb}-\mathrm{Cl}) .{ }^{1} \mathrm{H}$ NMR $\left(\mathrm{CDCl}_{3}, 295 \mathrm{~K}\right): \delta=2.19\left(\mathrm{br},[3 \mathrm{H}], \mathrm{CH}_{3}\right), 2.48\left(\mathrm{br},[3 \mathrm{H}], \mathrm{CH}_{3}\right)$, $2.76\left(\mathrm{br},[2 \mathrm{H}], \mathrm{CH}_{2}\right), 3.16\left(\mathrm{br},[2 \mathrm{H}], \mathrm{CH}_{2}\right)$.

Pale green crystals were grown by allowing a $\mathrm{CH}_{2} \mathrm{Cl}_{2}$ solution of the complex to evaporate under a $\mathrm{N}_{2}$ atmosphere. 


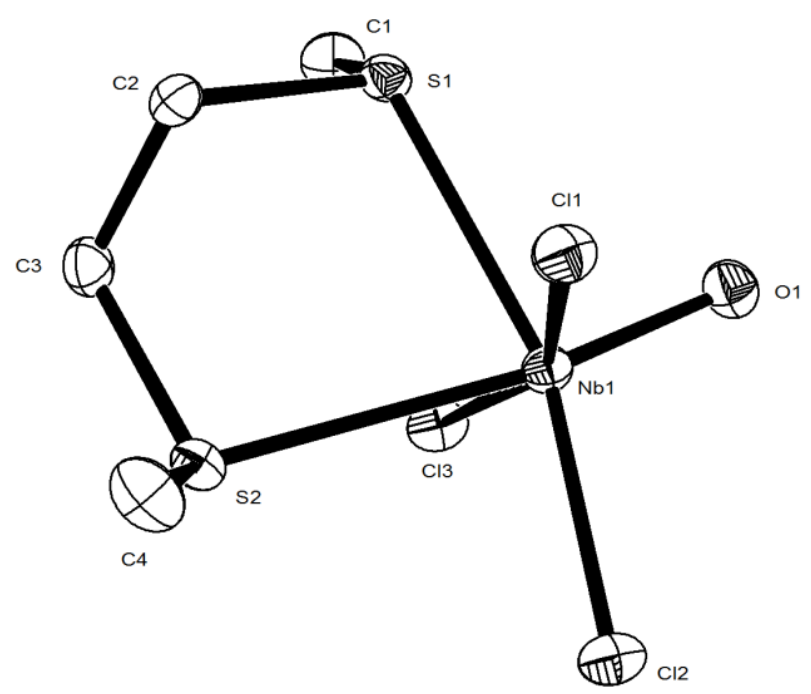

Figure S2. The structure of $\left[\mathrm{NbOCl}_{3}\left\{\mathrm{MeS}\left(\mathrm{CH}_{2}\right)_{2} \mathrm{SMe}\right\}\right]$ showing the atom numbering scheme and with ellipsoids drawn at the $50 \%$ probability level. Hydrogen atoms are omitted for clarity. Selected bond lengths $(\AA)$ and angles $\left({ }^{\circ}\right): \mathrm{Cl} 1-\mathrm{Nb} 1=2.375(1), \mathrm{Cl} 2-\mathrm{Nb} 1=2.339(1), \mathrm{Cl} 3-\mathrm{Nb} 1=2.369(1), \mathrm{O} 1-\mathrm{Nb} 1=1.718(4)$, $\mathrm{S} 1-\mathrm{Nb} 1=2.664(1), \mathrm{S} 2-\mathrm{Nb} 1=2.856(1) ; \mathrm{Cl1}-\mathrm{Nb} 1-\mathrm{Cl} 3=158.15(5), \mathrm{Cl} 2-\mathrm{Nb} 1-\mathrm{O} 1=105.17(15)$, $\mathrm{S} 1-\mathrm{Nb} 1-\mathrm{S} 2=77.50(4), \mathrm{O}(1)-\mathrm{Nb}(1)-\mathrm{Cl}(3)=97.22(14), \mathrm{Cl}(2)-\mathrm{Nb}(1)-\mathrm{Cl}(3)=97.03(5), \mathrm{O}(1)-\mathrm{Nb}(1)-\mathrm{Cl}(1)$ $=98.34(14), \mathrm{Cl}(2)-\mathrm{Nb}(1)-\mathrm{Cl}(1)=93.59(5), \mathrm{O}(1)-\mathrm{Nb}(1)-\mathrm{S}(1)=93.95(14), \mathrm{Cl}(3)-\mathrm{Nb}(1)-\mathrm{S}(1)=86.16(4)$, $\mathrm{Cl}(1)-\mathrm{Nb}(1)-\mathrm{S}(1)=77.56(4), \quad \mathrm{Cl}(2)-\mathrm{Nb}(1)-\mathrm{S}(2)=83.98(5), \quad \mathrm{Cl}(3)-\mathrm{Nb}(1)-\mathrm{S}(2)=76.86(5)$, $\mathrm{Cl}(1)-\mathrm{Nb}(1)-\mathrm{S}(2)=85.38(4)$.

\section{References}

S1. M. Ströbele and H.-J. Meyer, Z. Anorg. Allg. Chem., 2002, 628, 488.

\section{On the structure of $\left[\mathrm{Nb}_{2} \mathrm{Cl}_{4}\left(\mu-\mathrm{Se}_{x}\right)_{2}\left\{o-\mathrm{C}_{6} \mathrm{H}_{4}\left(\mathrm{CH}_{2}\right)_{2} \mathrm{Se}\right\}_{4}\right]$}

As briefly described in the main text there is some ambiguity over the bridging unit. The molecule exhibits inversion symmetry at the centre of the $\mathrm{Nb}_{2} \mathrm{Cl}_{2} \mathrm{Se}_{4+\mathrm{x}}$ core - the discussions below are with reference to the asymmetric unit.

Initial refinements proceed as expected with the large electron density peak refined as a single Se atom, this has the expected geometry for such a species forming a $\mu^{2}$ bridge (cf. Ta-Se in $\left[\mathrm{Ta}_{2} \mathrm{Cl}_{4}(\mu-\mathrm{Se})_{2}\{o-\right.$ $\left.\left.\left.\mathrm{C}_{6} \mathrm{H}_{4}\left(\mathrm{CH}_{2} \mathrm{SeMe}\right)_{2}\right\}_{2}\right]^{11} 2.484(2), 2.489(2) \AA\right)$. However, significant electron density remains asymmetrically above $(1.302 \mathrm{~A})$ and below $(0.982 \mathrm{~A})$ this site and free refinement of the occupancies give the values below, and the geometry of the 2 new positions is consistent with an $\mathrm{Se}_{2}$ unit ${ }^{29}$ (2.73(1), 2.65(1) $\AA$ ). The difficulty of interpretation arises from the occupancy sum of 1.0 so that a mixture of single bridge and double bridge situations cannot exist without also involving a partially vacant bridge site. The complex $\left[\mathrm{Nb}_{2} \mathrm{Cl}_{4}\left(\mathrm{~S}_{2}\right) \mathrm{S}(\mathrm{tht})_{4}\right]$ $\mathrm{S} 2$ is a sulphur bridged analogue of the minor component reported here.

\section{Refined occupancies of the electron density peaks:}

The difference peaks appear to represent real electron density (not Fourier truncation peaks).

Refined occupancies (EADP constraints) - 0.057, 0.89, 0.057

Refined occupancies (no ADP constraints) - 0.056, 0.89, 0.059

\section{Selected Bond lengths:}


$\mathrm{Nb} 1-\mathrm{Se} 3=2.4579(8) \AA$

$\mathrm{Nb} 1-\mathrm{Se} 3 \mathrm{a}=2.731 \AA(2.618,2.642,2.259 \AA)$

$\mathrm{Nb} 1-\mathrm{Se} 3 \mathrm{~b}=2.715 \AA$

$\mathrm{Se} 3 \mathrm{a}-\mathrm{Se} 3 \mathrm{~b}=2.283 \AA(2.259 \AA)$

$\mathrm{Nb} 1-\mathrm{Nb} 1^{\mathrm{i}}=2.898 \AA(2.972 \AA)$

Values in parentheses are from Reference 29 for comparison.

\section{Refinement:}

EADP Se3, Se3a \& Se3b was required to retain realistic thermal parameters.

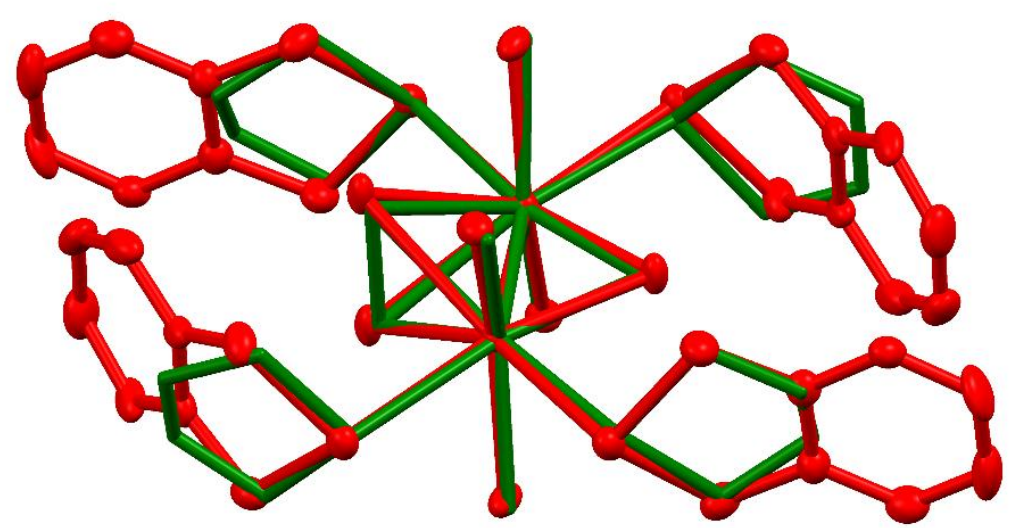

Overlay of CCDC CAMZUL $(\mathrm{Nb}-\mathrm{S})^{\mathrm{S} 2}$ and the current structure $(\mathrm{Nb}-\mathrm{Se})$ comparing the potentially similar bridging arrangements.

The minor species could also be interpreted as a single bridging Se with a butterfly shape (sometimes sitting above and sometimes below the plane of the major species). We thank a reviewer for this suggestion. 


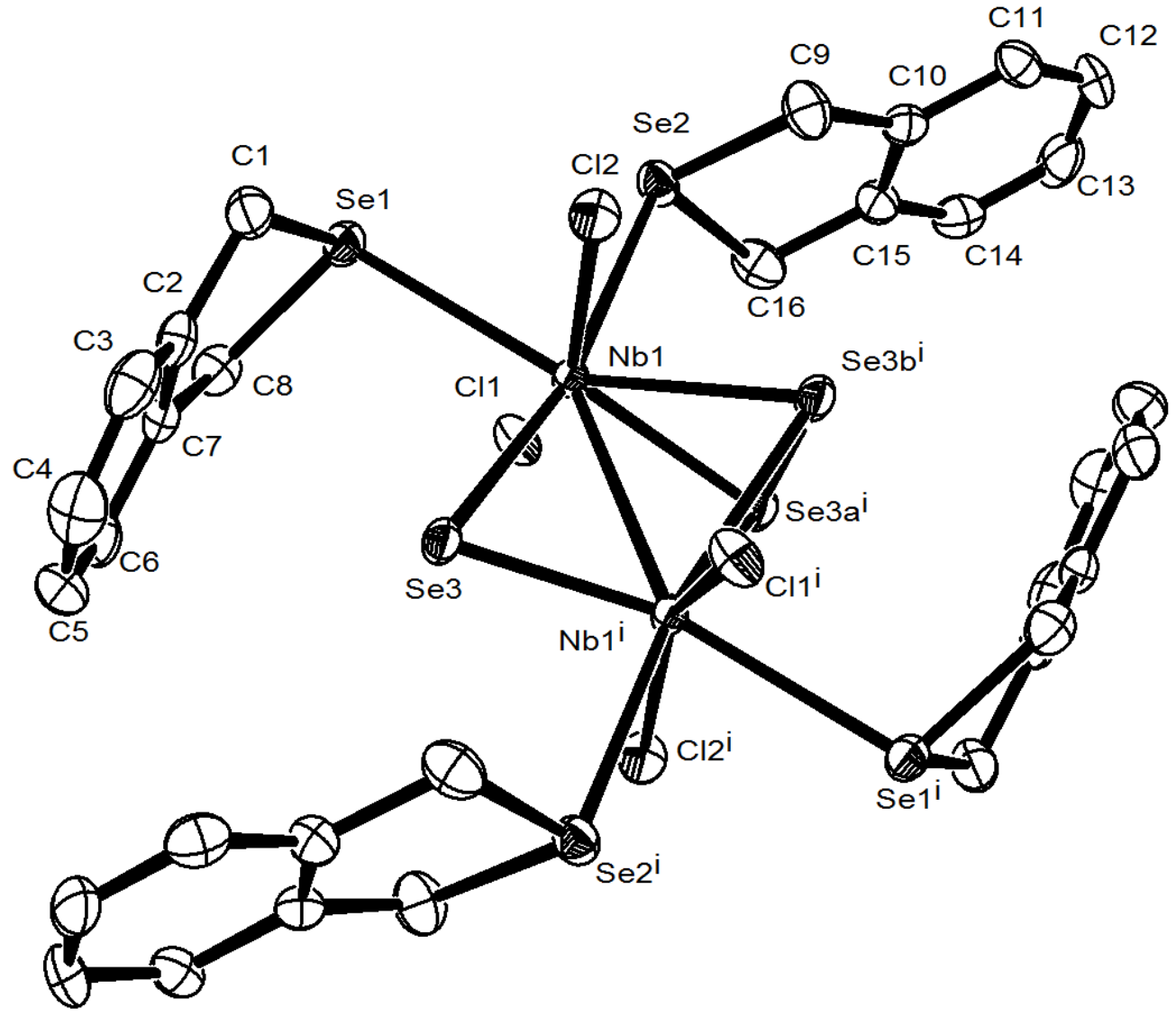

Figure S3. The structure of $\left[\mathrm{Nb}_{2} \mathrm{Cl}_{4}\left(\mu-\mathrm{Se}_{2}\right)(\mu-\mathrm{Se})\left\{o-\mathrm{C}_{6} \mathrm{H}_{4}\left(\mathrm{CH}_{2}\right)_{2} \mathrm{Se}\right\}_{4}\right]$ as refined showing the atom numbering scheme and with ellipsoids drawn at the 50\% probability level. Hydrogen atoms are omitted for clarity. Selected bond lengths $(\AA)$ and angles $\left({ }^{\circ}\right)$ : Nb-Cl1 $=2.384(1), \mathrm{Nb} 1-\mathrm{Cl} 2=2.372(2), \mathrm{Nb} 1-\mathrm{Nb} 1^{\mathrm{i}}=$ 2.8980(9), $\mathrm{Nb} 1-\mathrm{Se} 1=2.8266(8), \mathrm{Nb} 1-\mathrm{Se} 2=2.8214(7), \mathrm{Nb} 1-\mathrm{Se} 3=2.4578(8), \mathrm{Nb} 1-\mathrm{Se} 3 \mathrm{a}^{\mathrm{i}}=2.73(1)$, $\mathrm{Nb} 1-\mathrm{Se}_{3} b^{\mathrm{i}}=2.65(1) ; \mathrm{Cl} 1-\mathrm{Nb} 1-\mathrm{Cl} 2=152.68(6), \mathrm{Se} 1-\mathrm{Nb} 1-\mathrm{Se} 2=79.79(2)$. Symmetry operation: $\mathrm{i}=1-\mathrm{x},-$ $\mathrm{y},-\mathrm{z}$. 
Table S1 X-ray crystallographic data

\begin{tabular}{|c|c|c|}
\hline Compound & {$\left[\mathrm{NbOCl}_{3}\left(\mathrm{SMe}_{2}\right)\right]$} & {$\left[\mathrm{NbOCl}_{3}\left\{\mathrm{MeS}\left(\mathrm{CH}_{2}\right)_{2} \mathrm{SMe}\right\}\right]$} \\
\hline Formula & $\mathrm{C}_{2} \mathrm{H}_{6} \mathrm{Cl}_{3} \mathrm{NbOS}$ & $\mathrm{C}_{4} \mathrm{H}_{10} \mathrm{Cl}_{3} \mathrm{NbOS}_{2}$ \\
\hline Formula weight & 277.39 & 337.5 \\
\hline Crystal system & Monoclinic & Triclinic \\
\hline Space group (no) & $\mathrm{P} 2{ }_{1} / \mathrm{c}(14)$ & P1 (1) \\
\hline a/ $\AA$ & $14.352(1)$ & $6.7898(3)$ \\
\hline $\mathrm{b} / \AA$ & $14.9254(7)$ & $6.9745(3)$ \\
\hline c/ $\AA$ & $7.9099(5)$ & $7.2523(4)$ \\
\hline$\alpha / \operatorname{deg}$ & 90 & $108.917(4)$ \\
\hline$\beta / \operatorname{deg}$ & $97.049(7)$ & $99.404(4)$ \\
\hline$\gamma / \operatorname{deg}$ & 90 & $113.677(4)$ \\
\hline $\mathrm{U} / \AA^{3}$ & $1681.6(2)$ & $279.93(3)$ \\
\hline $\mathrm{Z}$ & 8 & 1 \\
\hline$\mu(\mathrm{Mo}-\mathrm{K} \alpha) / \mathrm{mm}^{-1}$ & 2.548 & 2.112 \\
\hline $\mathrm{F}(000)$ & 1072 & 166 \\
\hline Total no. reflections & 13175 & 6650 \\
\hline Unique reflections & 3295 & 2205 \\
\hline $\mathrm{R}_{\text {int }}$ & 0.079 & 0.033 \\
\hline $\begin{array}{l}\text { No. of parameters, } \\
\text { restraints }\end{array}$ & 149,0 & 102,3 \\
\hline $\mathrm{R}_{1}^{\mathrm{b}}\left[\mathrm{I}_{\mathrm{o}}>2 \sigma\left(\mathrm{I}_{\mathrm{o}}\right)\right]$ & 0.041 & 0.025 \\
\hline $\mathrm{R}_{1}$ (all data) & 0.074 & 0.027 \\
\hline $\mathrm{wR}_{2}^{\mathrm{b}}\left[\mathrm{I}_{\mathrm{o}}>2 \sigma\left(\mathrm{I}_{\mathrm{o}}\right)\right]$ & 0.069 & 0.062 \\
\hline $\mathrm{wR}_{2}$ (all data) & 0.080 & 0.063 \\
\hline
\end{tabular}

Reference S2. M. G. B. Drew, D. A. Rice and D. M. Williams, J. Chem. Soc., Dalton Trans., 1983, 2251. 